IRSH 63 (2018), pp. 239-27I doi:10.1017/S00208590I8000317

(C) 2018 Internationaal Instituut voor Sociale Geschiedenis

\title{
The Land-Labour Hypothesis in a Settler Economy: Wealth, Labour, and Household Composition on the South African Frontier
}

\author{
JEANNE CiLliteRs \\ Department of Economic History, Lund University, \\ Box 7083, 22007 Lund, Sweden \\ E-mail: jeanne.cilliers.7367@ekh.lu.se \\ ERIK GREEN \\ Department of Economic History, Lund University, \\ Box 7083, 22007 Lund, Sweden \\ E-mail: Erik.Green@ekh.lu.se
}

\begin{abstract}
Traditional frontier literature identifies a positive correlation between land availability and fertility. A common explanation is that the demand for child labour is higher in newly established frontier regions compared to older, more densely populated farming regions. In this paper, we contribute to the debate by analysing the relationship between household composition and land availability in a closing frontier region, i.e. the Graaff-Reinet district in South Africa's Cape Colony from I798-I 828. We show that the number of children in farming households increased with frontier closure, while the presence of non-family labourers decreased over time. Contrasting with the classic interpretation, we explain this by acknowledging that the demand for family labour was not a function of its marginal productivity and that farmers reacted differently to diminishing land availability depending on their wealth. Poorer households, which made up the majority of this frontier population, responded to shrinking land availability by employing relatively more family labour, while the wealthiest group invested in strengthening market access.
\end{abstract}

\section{INTRODUCTION}

In the r960s and I970s, scholars found that the decline in fertility in the nineteenth-century Western world could not be fully understood without considering population dynamics in rural areas. The findings inspired a revision of the mechanisms of demographic transition, as previous research 
had largely focused on the channels of urbanization and industrialization. ${ }^{\mathrm{I}}$ Looking then to the fertility decline in nineteenth-century rural US, scholars found that fertility systematically varied with population densities. Fertility levels were, on average, higher in less densely populated frontier regions compared to the already established and more populous settler regions. ${ }^{2}$ This pattern has also been found in other parts of the world - past and present. ${ }^{3}$

While the positive correlation between land availability and fertility has received much empirical support, the transmission channels that explain this relationship have not yet been well established. The most common explanation is the so-called land-labour hypothesis. There are two different versions of the hypothesis. One argues that the positive relationship between land availability and fertility is due to the lower relative costs of having children in frontier regions, and a second claims that the differences in fertility levels are caused by a higher demand for child labour in newly established and less densely populated frontier regions. ${ }^{4}$ In this paper, we contribute to the debate by analysing the relationship between land availability and the presence of children in settler farming households in the Cape Colony.

From its origins as a refreshment station controlled by the Dutch East Indian Company, the Cape gradually evolved into a settler colony over the seventeenth century. Initial European settlement was concentrated in the southwestern region of the colony where the terrain and Mediterranean climate were well suited to the production of wheat and wine. But strict trade regulations made farming for the Company unprofitable and many stock farmers advanced further into the interior in search of better pasture,

I. Kingsley Davis, “The World Demographic Transition”, The Annals of the American Academy of Political and Social Science, 237: I (1945), pp. I-I I; Frank W. Notestein, Population: The Long View (Chicago, IL, 1945).

2. Yasukichi Yasuba, Birth Rates of the White Population in the United States, I800-I860: An Economic Study (Baltimore, MD, I962); Richard Easterlin, "Population Change and Farm Settlement in the Northern United States", The Journal of Economic History, $36:$ I (1976), pp. 57-I 34; Richard Easterlin, "Factors in the Decline of Farm Family Fertility in the United States: Some Preliminary Research Results", The Journal of American History, 63:3 (1976) pp. 600-6i 4; Richard Easterlin et al., "Farms and Farm Families in Old and New Areas: The Northern States in I 860", in Tamara K. Hareven and Maris A. Vinovskis (eds), Family and Population in NineteenthCentury America (Princeton, NJ, 1978). pp. 22-84; Geraldine Mineau et al., "Migration and Fertility: Behavioural Change on the American Frontier”, Journal of Family History, I 4: I (1989), pp. 43-6I.

3. Andrea Doveri, "Land, Fertility, and Family: A Selected Review of the Literature in Historical Demography", Genus, 56:3/4 (2000), pp.19-59; David Carr et al., "Declining Fertility on the Frontier: The Ecuadorian Amazon”, Population and Environment, 28: (2007), pp. 17-39.

4. For an overview, see R.M. McInnis, "Childbearing and Land Availability: Some Evidence from Individual Household Data", in Ronald Demos Lee (ed.) Population Patterns in the Past (New York, 1977), pp. 20I-227. 
water, and freedom from Company rule, resulting in an ever-expanding frontier.' Since we are interested in frontier dynamics, this paper will consider the settler population of the Graaff-Reinet district at the eastern frontier in South Africa's Cape Colony from I798-I 828. The district was formally established in 1786 and by 1840 had become the centre of the Cape wool industry. The intervening period saw a steady inflow of European settlers to the region engaging predominantly in pastoral pursuits. Differently from the southwestern Cape the use of slaves was not widespread in Graaff-Reinet. The holding of slaves, originally imported from eastern Africa, was concentrated in the hands of the wealthiest and their employment on frontier farms was surpassed by both indigenous Khosian and family labour. During our period of investigation, the Graaff-Reinet frontier was gradually closing as a result of population growth, increased scarcity in natural resources, and recurrent political tensions. The question we ask is how the process of frontier closure affected both the number of children present in the household and the relative presence of non-family labour. To answer this question, we combine two rich data sources: the Cape of Good Hope Panel (CGHP) and the South African Families database (SAF), which are both unique in their size and scope across time and space. The CGHP is an annual account of household production in colonial South Africa, covering the period I673-1828, and SAF is a genealogical register of all settler families in South Africa, covering the period 1652I9I0. The combination of these two sources provides the opportunity to model changing household composition over time.

Our data allow us to conduct fine-tuned analysis of the relationship between land availability and household composition. It enables us to consider the number of children present in a settler household in a given census year. This is a more accurate representation of the size of the annual family labour force than children ever-born or completed fertility. Further, we relate the changing household composition to the real value of contemporary household wealth, rather than wealth at death, as is often the case with studies that rely on wills or probate inventories. This distinction is important because both fertility and wealth have clear lifecycle trends.

In contrast to the traditional frontier literature, we find a negative correlation between land availability and family size when the frontier was closing. Data constraints prevent us from empirically identifying causation and we instead rely on theories of agrarian change to interpret our findings, making two additional distinctions: First, we differentiate between the relative use of family and non-family labour. The demand of the former is 
dependent on the marginal productivity of labour, while the latter is not. ${ }^{6}$ The type of labour used, therefore, has a significant impact on how farmers react to shrinking land availability, and the demand for child labour requires a revision of the standard cost-benefit analysis employed by the proponents of the land-labour hypothesis.

Secondly, we are able to distinguish between different wealth groups. The rationale behind this is that farming households' strategies to cope with diminishing land availability depends on the means available to them to adjust farming systems. We find that different wealth groups responded differently: over time, the poor majority reported higher numbers of settler children present, while the wealthiest households did not. Based on our findings, we argue that the wealthiest farmers responded to the changing circumstances by investing instead in increased market access, while those who lacked the means to make major capital investments reacted by increasing their relative use of family labour.

\section{THE LAND-LABOUR HYPOTHESIS}

While traditional frontier literature finds a positive correlation between land size and demand for children, the rich literature on population and agrarian change in pre-industrial societies gives reasons to believe that it is equally plausible that the relationship was negative. A cornerstone of this body of literature is Boserup's seminal work on population pressure and changes in agricultural systems. Where frontier literature explains how land availability affects fertility, Boserup develops a model to explain the effect of increased population pressure (caused by increased fertility or migration) on farming practices. Boserup's work is often cited as a response to Malthus's pessimistic account of the effect of population growth on output and rural welfare.

Malthus argued that increased population pressure would lead to a decline in production per capita and consequently - in the long run - a reduction in population size. ${ }^{7}$ The reason is that without so-called positive or preventive checks, the population would increase geometrically while food production would increase arithmetically. An increase in per capita income above an equilibrium level of consumption leads to population growth. Since land is assumed to be a fixed factor of production, continued increase in population implies that marginal lands will have to be opened for cultivation. This leads to a slowdown in agricultural growth and hence

6. Ester Boserup, The Conditions of Agricultural Growth: The Economics of Agrarian Change under Population Pressure (New Brunswick, NJ, 1965); Alexander V. Chayanov Theory of Peasant Economy (Madison, WI, I986); Philip Huang, The Peasant Family and Rural Development in the Yangzi Delta, 1350-1988 (Stanford, CA, 1990).

7. Thomas R. Malthus, Essay on the Principle of Population (London, 1798). 
diminishing output per capita. Mortality levels would increase until the per capita consumption falls back to its original equilibrium. This is often referred to as the Malthusian trap or low-level equilibrium. ${ }^{8}$

Boserup challenged the Malthusian relationship between population and agricultural output. In short, Boserup claims that the rural population would respond to increased population pressure by adopting more intensive farming practices and increasing the frequency of cropping. In this way, output per capita could be kept intact or even increase with population growth. Land-use intensification, by way of shorter periods of fallow, for example, leads to increased yields per unit of land, but also requires more labour and/or capital. In the pre-mechanization period, land-intensification thus came at the cost of declining labour productivity. In contrast with the land-labour hypothesis, under these conditions, farmers can react to shrinking land availability by having more children, who can be put to work in order to maintain output per capita. We expect to find such a relationship only in cases where farmers mainly rely on the use of family labour, as farmers will employ this form of labour even when the marginal productivity is decreasing. ${ }^{9}$

But why would farmers increase labour input instead of moving towards more capital intensive farming systems? One of the most influential theories of technical change (change in farming practices and/or technologies) is Hayami and Ruttan's model of induced innovation. ${ }^{10}$ They treat technical change as endogenous. In brief, they argue that as agriculture develops over time, particular resources become scarce, which affects the relative factor prices of inputs. In cases of land abundance and labour scarcity, farmers would seek innovations that increase land productivity, i.e. yield-increasing technologies. In this regard, their model is similar to a Boserupian interpretation of agrarian change. But while Boserup focuses on the landpopulation relationship, induced-innovation focuses more broadly on all factors of production, including both embodied and disembodied technologies.

Critics have pointed out that Hayami and Ruttan's model depends on the existence of private or public organizations that respond to the changing factor prices by developing new innovations and making them available for

8. Thomas Kögel and Alexia Prskawewtz, "Agricultural Productivity Growth and Escape from the Malthusian Trap", Journal of Economic Growth, 6 (200I), pp. 337-357.

9. Giovanni Cornia, "Farm Size, Land Yields and the Agricultural Production Function: An Analysis for Fifteen Developing Countries", World Development, I 3:4 (1985), pp. 5 I 3-534; Keith Griffin et al., "Poverty and the Distribution of Land", Journal of Agrarian Change, 2:3 (2002), pp. 279-330; Gareth Austin, Labour, Land, and Capital in Ghana: From Slavery to Free Labour in Asante, I807-1956 (Rochester, NY, 2004).

ı. Yūjirō Hayami and Vernon Ruttan, Agricultural Development: An International Perspective (Baltimore, MD, 1985 ). 
farmers. ${ }^{\text {I }}$ In our case, such organizations were clearly missing. The best way to access new technologies was either to produce them on the farm, or travel to the market - a journey that could take several weeks. Equally important, and as pointed out in the extensive research on agricultural development in currently developing regions, farmers must have the means to purchase the innovations. ${ }^{\mathrm{I}}$ In a case of fragmented markets and limited purchasing power, farmers may not respond to changing relative factor prices in the way that the model presupposes. More precisely, farmers may respond differently to changing factor prices according to their wealth and access to markets.

Let us consider an agrarian settler society consisting of two groups: one wealthy group and with the means to develop more capital intensive farms and/or employ additional family or non-family labour, and a poor group that faces capital scarcity and relies solely on family labour. The latter group would respond to shrinking land availability by having more children, who could be put to work. For this group, we expect a negative correlation between land availability and family size. This relationship may be temporary as Boserup suggests, or long-term as was the case in pre-industrial Asia and other parts of Africa. ${ }^{13}$ The wealthier group would respond by either employing additional labour and/or developing more capital intensive farming methods. For this group, we expect to find no correlation or a positive correlation between land availability and family size.

This means that the wealth of farmers has both a direct and indirect impact on the relationship between land availability and family size - direct, as the level of wealth affects the means available to respond to shrinking land availability, and indirect as the wealth affects the type of labour employed as farm workers. In a context where the majority of farmers were poor, we expect the closing of an agrarian frontier to be associated with an increase in the number of settler children present in farming households.

Although the literature on farming systems and labour is mainly concerned with crop farming, it also has a bearing on pastoral farming. Intensification is a relative measure and while it is true that crop farming in general is more labour intensive, some pastoral farming systems require more labour input than others. In times of shrinking grazing land availability, pastoral farmers can react in different ways to maintain output

I I. Frank Ellis, Peasant Economics: Farm Households and Agrarian Development (Cambridge, I993), pp. 234-235.

I2. Griffin et al., "Poverty and the Distribution of Land".

I 3. Huang, The Peasant Family; Montserrat Lopez Jerez, "Deltas Apart: Factor Endowments, Colonial Extraction and Pathways of Agricultural Development in Vietnam" (Ph.D., Lund University, 20I4); Erik Green, "From Extensive to Involutionary Growth: A Dialectic Interpretation of the Boom and Busts of Cocoa Production in the Gold Coast", Journal of Agrarian Change, I7:3 (2016), pp. 518-534. 
and/or income. Wealthier farmers could capital intensify, for example, by investing in more productive, but also more expensive, livestock or invest in transportation to increase market access. Farmers that lack the means to take such measures could invest in less productive and less land-demanding but more labour intensive livestock. Even in pastoral communities we therefore expect that the wealth of farmers would determine whether the correlation between land availability and fertility is negative or positive. We explore this relationship further in the context of the closing Graaff-Reinet frontier.

\section{THE GRAAFF-REINET FRONTIER}

The Cape was initially settled by the Dutch East India Company (VOC) as a refreshment station for passing ships. Gradually, the number of European inhabitants increased, and by the early eighteenth century, the Cape had established itself as a settler colony, supplying Cape Town and passing ships primarily with wheat, wine, fresh produce, and meat. Most European farmers settled in the southwestern part of the Cape, but by the mideighteenth-century, expansion into the eastern and northern interior was well underway (see Figure I). ${ }^{\mathrm{I}}$ During this time, the European population at the Cape was doubling approximately every generation. ${ }^{15}$ The district of Graaff-Reinet, on the eastern frontier of the Cape Colony, was established in 1786 , accounting for around a third of the total extent of the colony and covering an area of approximately 50,000 square miles. ${ }^{16}$ There, agroclimatic conditions favoured pastoralism, and stock farming quickly became the dominant economic activity. As early as 1770 , two thirds of inland farmers were estimated to have been engaged in livestock pursuits rather than as cultivators. ${ }^{17}$ Unlike the frontier expansion in North America, the expansion eastward in the Cape saw movements of people followed gradually by commercial development. ${ }^{18}$

Sons of the poorer arable farmers of the southwestern Cape likely viewed stock farming on the interior as an attractive means of survival, since entry requirements were low and the product could walk to market. During its formative years, it was possible for a settler with little to no capital to move

I4. Leonard Guelke, "Freehold Farmers and Frontier Settlers, I657-1780", in Richard Elphick and Hermann Giliomee (eds), The Shaping of South African Society, I652-I 840 (Middletown, CT, 1989), pp. 84-93.

I 5. Robert Ross, Beyond the Pale: Essays on the History of Colonial South Africa (London, 1993) p. 138 .

16. Henning, Graaff-Reinet, p.3.

I7. Guelke, "Freehold Farmers", p. 85 .

I8. Hermann Giliomee "Processes in Development of the Southern African Frontier", in Howard Lamar and Leonard Thompson (eds) The Frontier in History: North America and Southern Africa Compared (London, 198I) pp. 76-1 19. 


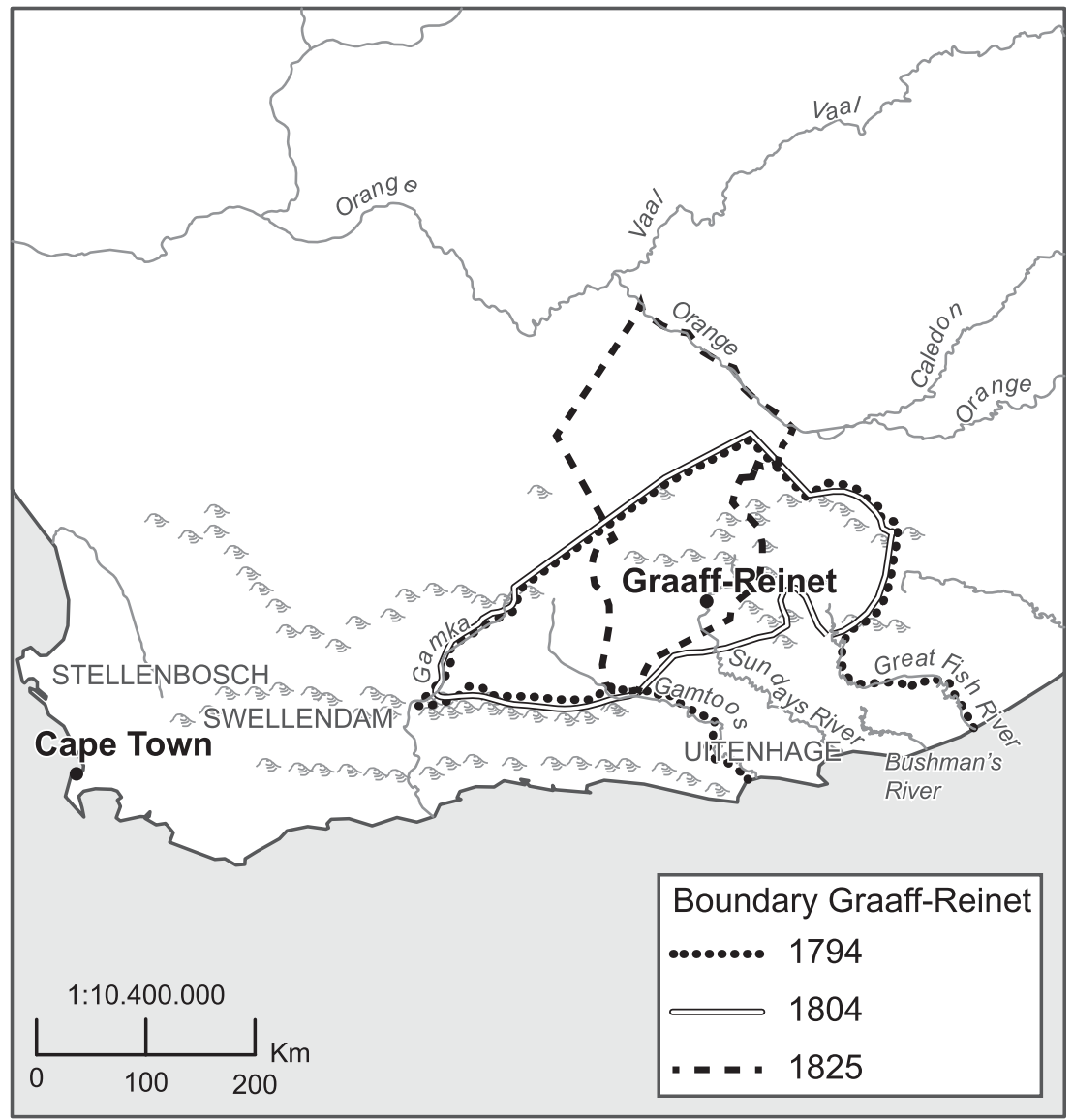

Figure I. The Graaff-Reinet district expansion from 1795 to I 825 .

into the Graaff-Reinet district and set up a farm. In the late I770s, a local farmer's wife remarked to the Swedish traveller Sparrman,

You have already a wagon, oxen, and saddle horses; these are the chief things requisite in order to set up as a farmer; there are yet uncultivated places in the neighbourhood, proper either for pasturage or tillage, so that you may choose out of an extensive tract of land the spot that pleases you the best. ${ }^{19}$

Some doubt has been cast on whether it truly was this easy for poor frontiersmen to set up as productive stock farmers; ${ }^{20}$ nevertheless, the

19. Quoted in Neumark, Economic Influences, p. 37.

20. Newton-King, “The Enemy Within", p. 48. 
steady inflow of new settlers to the district continued into the nineteenth century and the best grazing lands were quickly snatched up. A farm of some 6,000 acres could be acquired under the land grant system with relative ease.

The extent to which frontier households were isolated and independent from trade with the domestic market has been the subject of some debate in the South African historiography. While some paint an image of a wayward, solitary, semi-nomadic, and self-sufficient brand of frontiersman, ${ }^{21}$ others maintain that households on the frontier remained relatively orthodox and geared towards production for the market in order to provide for their daily needs. ${ }^{22}$ While scattered evidence of the former can be found, the consensus is that although these households were able to meet some of their basic needs themselves, they were "never entirely cut off from the exchange economy of the south-western Cape". ${ }^{23}$ On the inhabitants of the GraaffReinet district, it has been remarked that "highlights in the lives of the stock farmers were occasional treks to Cape Town, to pay their recognition fees, to marry, to baptize children, to obtain provisions, to redeem their bills. On such occasions the Boers ${ }^{24}$ took cattle with them to sell in Cape Town, and commodities such as butter and soap". ${ }^{25}$ Indeed, Guelke acknowledges that the expansion of this group of frontier famers could not have taken place without "guns, gunpowder, wagons and other manufactured items obtainable only in exchange for the produce of the interior". ${ }^{26}$

While the long distance to major markets in the southwestern Cape limited the degree of commercialization, the sale of cattle and sheep still constituted the main source of cash income. ${ }^{27}$ One contemporary traveller, a German doctor of medicine and philosophy, formerly in the Dutch service at the Cape of Good Hope, Henry Lichtenstein, wrote optimistically on large profits to be had from stock farming in this region. He remarked that sheep in this district were favoured above all others in the colony for their weightiness and flavoursome meat. He estimated that "some farmers [had]

2 I. Guelke, "Freehold Farmers", p. 87.

22. Solomon Daniel Neumark, Economic Influences on the South African Frontier (Stanford, CA, 1957); Peter van Duin and Robert Ross, The Economy of the Cape Colony in the I 8th Century (Leiden, 1987); Susan Newton-King, Masters and Servants on the Cape Eastern Frontier: 1760I803 (Cambridge, 1999).

23. Susan Newton-King, "The Enemy Within: The Struggle for Ascendancy on the Eastern Cape Frontier, 1760-1800" (Ph.D., University of London, I992), p. 39.

24. Boers (translated directly from Afrikaans, means farmers) is the collective name given to the settler population group of Dutch and French ancestry.

25. Kenneth Wyndham Smith, "From Frontier to Midlands, A History of the Graaff-Reinet District, I786-1910" (Ph.D., Rhodes University, 1974), p. I I.

26. Guelke, "Freehold Farmers," p. 88.

27. William Beinart, The Rise of Conservation in South Africa: Settlers, Livestock, and the Environment, 1770-1950 (Oxford, 2008), p. I0. 
flocks to the amount of six or seven thousand". Cows here reportedly "gave richer milk than elsewhere, and in greater abundance" with butter "carried in great quantities to Cape Town, where it [was] always eagerly bought up". ${ }^{28}$

Allowing for vegetative and seasonal differences, it has been estimated that one sheep or goat required roughly four acres of grazing land, whereas one horse or head of cattle required some eighty acres - a fact that likely contributed to the prevalence of small stock over cattle holding in the frontier districts. ${ }^{29}$ While sheep farming is relatively non-labour intensive compared to crop farming, this was less true in the nineteenth century. Shepherds played an invaluable role at a time before fencing was a mainstay and amidst the ever-present threat of predation or theft by Khoisan raiders. Daily kraaling ${ }^{30}$ meant that each flock of a few hundred heads required a dedicated shepherd. ${ }^{3 \mathrm{I}}$

Where land was to be had on the frontier, ownership was almost exclusively conferred in accordance with the loan farm system, which offered temporary land-use permits in exchange for annual rents. ${ }^{32}$ There is little evidence to suggest that this system created inherent insecurity, since it conferred tenants with exclusive rights to their fixed plot of land. In addition to permits being indefinitely renewable, settlers were free to farm their land without any restrictions or fear of interference from governing authorities. Moreover, applications for licences and permits were seldom refused. Smith notes that "while the Company did not legally surrender its right to take back a loan farm, this was so seldom done that the Boers came to accept that the farms were their own, until they decided to leave; even the failure to pay recognition fees did not result in the revocation of a permit". ${ }^{33}$

While the land could not technically be sold, settlers could transfer the improvements, resulting in a system of de facto permanent property rights. ${ }^{34}$ In contrast with the visible "affluence and prosperity" of many

28. Henry Lichtenstein, Travels in Southern Africa in the Years I809, I804, I805 and I806. A Plumptre, trans. Two vols. Cape Town (2nd vol. I930), p. 5.

29. Saul Dubow, Land, Labour and Merchant Capital in the Pre-Industrial Rural Economy of the Cape: The Experience of the Graaff-Reinet District (I852-72) (Cape Town, 1982), p. 2.

30. The practice whereby the shepherd allows his flock to graze by day and then returns them to their kraals at night.

31. Dubow, Land, Labour and Merchant Capital, p. 36; on the process of fencing and the consequences for the labour relations, see Fredrik Lilja, "Inside the Enclosed Farm: Farmers, Shepherds, and the Introduction of New Technology in Cape Wool Farming, I865-1950", International Review of Social History, 63:I (2018), pp. 63-89.

32. Colin Graham Botha, Early Cape Land Tenure (Cape Town, 1919).

33. Smith, "From Frontier to Midlands", p. 9.

34. Laura Mitchell, Belongings: Property, Family, and Identity in Colonial South Africa (An Exploration of Frontiers, $1725-$ - . 1830 ) (New York, 2009), p. 34. 
farmers in the southwestern Cape, ${ }^{35}$ a salient feature of life on the frontier was the high proportion of virtually impoverished farmers. ${ }^{36}$ That is not to say that a small "landed gentry" did not exist, but the majority of pastoral farmers of the frontier it seems, struggled to make ends meet. ${ }^{37}$

Labour demands on the frontier were always high and in times of acute labour shortage, "all who could be exploited as labourers, were exploited". ${ }^{38}$ This was true for many colonial economies in Africa, ${ }^{39}$ where the incorporation of native and child labour, both free and unfree, kin and nonkin, was viewed as a necessary and acceptable means of meeting domestic production needs, as well as to supply the ever-expanding European market. ${ }^{4}$

There were three main sources of labour available to the frontier farmer: family, slave, and indigenous Khoisan. The importation of slaves to the colony began in 1658 , but only flourished at the beginning of the eighteenth century. By I 793 , there were I 4,747 slaves in the colony compared to I 3,830 Europeans. ${ }^{4 \mathrm{I}}$ Unlike the wine and wheat farmers of the regions closest to Cape Town, frontier stock farmers kept comparatively few slaves and while many carried with them the attitudes of a slave holding community, most could only afford to keep one or two. ${ }^{42}$ The average number of slaves per household calculated from the Graaff-Reinet Opgaafrollen for the period I798-I 828 is I.2 (see Figure 2). This closely matches the traveller John Barrow's contemporary reckoning that in the district of Graaff-Reinet, in the last decade of the eighteenth century, there were no more than six or seven hundred slaves; approximately one to each family. Moreover, a detailed return for the field cornets office of Op Sneeuwberg (a sub-district of Graaff-Reinet) for I 808 , suggests, too, that the distribution of slaves was highly uneven, and that most of the 197 slaves present in that year were

35. Johan Fourie, "The Remarkable Wealth of the Dutch Cape Colony: Measurements from Eighteenth-Century Probate Inventories", The Economic History Review, 66:2 (2013), 419-448, $42 \mathrm{I}$.

36. Newton-King, Masters and Servants, p. 300.

37. Wayne Dooling, "The Making of a Colonial Elite: Property, Family and Landed Stability in the Cape Colony, c.1750-1834", Journal of Southern African Studies, 3 I:I (2005), pp.147-162.

38. Dubow, Land, Labour and Merchant Capital, p. 46.

39. Beverly Grier, "Child Labour in Colonial Africa", in Hugh D. Hindman (ed), The World of Child Labour: An Historical and Regional Survey (New York, 2009), p. 173.

40. This was also true for pre-industrial England, where child labour was not perceived negatively. To the contrary, it has been suggested that "eighteenth- century poor law records saw idleness of children as a problem" (Cunningham, quoted in Joyce Burnett, "Child Day-Labourers in Agriculture: Evidence from Farm Accounts, 1740-1 850", The Economic History Review, 65:3 (201 2), pp. 1077-I099, I078).

4I. Nigel Worden, Slavery in Dutch South Africa (Cambridge, 1985), p. I I

42. Barrow, quoted in Elizabeth A. Eldredge, "Slave Raiding Across the Cape Frontier", in Elizabeth A. Eldredge and Fred Morton (eds), Slavery in South Africa: Captive Labour on the Dutch Frontier (Boulder, CO [etc.], 1994), pp. 93-1 27, 96. 


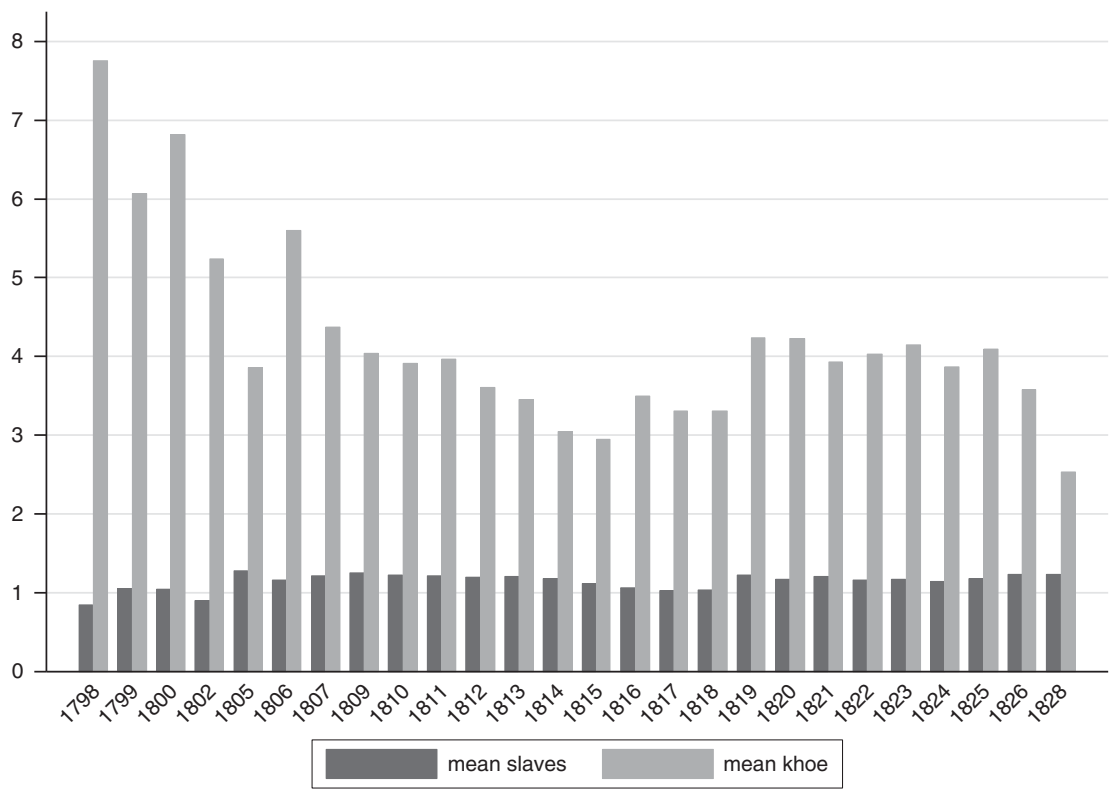

Figure 2. Mean number of slaves and Khoe employed on settler farms annually, 1798-1828.

concentrated in the hands of the wealthiest inhabitants. ${ }^{43}$ Before 1806 , when the British banned the importation of slaves, farmers could have bought newly arrived slaves at the slave auctions in Cape Town. Others may have purchased slaves from other farmers the commercial centre of the southwestern Cape and occasionally non slave-owners may have hired slaves from the large slaveholders, as happened in the southwestern Cape ${ }^{44}$ But Lichtenstein recalls a passage from the journal of a friend, who, during his visit to the Graaff-Reinet home of "one of the most substantial men the country", described that the situation of the slaves was "truly lamentable, for he [the farmer] only brought such from Cape Town as were to be purchased at a very cheap rate". ${ }^{5}$ Barrow noted, too, that Boers preferred the Khoe as labourers because slaves were too expensive. ${ }^{46}$ Indeed, according to the Opgaafrollen, indigenous Khoisan made up the majority of the agricultural labour force on the eastern frontier (see Figure 2). ${ }^{47}$ Note

43. Smith, "From Frontier to Midlands", p. 336.

44. Erik Green, "The Economics of Slavery in the Eighteenth-Century Cape Colony: Revising the Nieboer-Domar Hypothesis”, The International Review of Social History, 59:I (2014), pp. 39-70, 65. 45. Lichtenstein, Travels in Southern Africa, p. 8.

46. John Barrow, An Account of the Travels into the Interior of Southern Africa in the Years 1797I789, (London, I 801), p. I63.

47. John Illife, "The South African Economy, I652-1997", The Economic History Review, 52:I (1999), pp. 87-103, 90. 
that the Khoisan we are able to capture in our data are limited to those working on European farms. The true population was likely far greater, as some Khoisan were employed by the colonial government, while others managed to survive as independent pastoralists.

Lack of reliable information on the latter prevent us from making even an educated guess regarding the size of the total Khoisan population in the district. Some Khosian will have been residing in the district prior to the arrival of the Europeans, while some may have had originated from the northern and southwestern Cape and accompanied the Europeans as they moved into the interior, working for them as interpreters, carriers, and domestic servants. The Khoisan residing on the European farms consisted of captured runaways (who had joined the Xhosa fighting against further European expansion), apprentices, and "free" men, who, having lost their kraals were left with no other choice than to work for Europeans. ${ }^{8}{ }^{8}$ The latter group was the most important source of non-family labour in the district, reportedly often living in dismal conditions on their employers's farms. Traveller John Campell recalled in I 822 that the conditions for some Khoe labourers were often worse than that of the slaves. ${ }^{49}$ However, the daily lives and circumstances of these two groups cannot be thought of as distinct from one another. As Mason argues:

Slaves lived and worked beside these servants, performing the same tasks shepherd, cattleherd, field labourer, household servant, and sometimes overseer and experiencing the same forms of labour control, which was a blend of coercion and incentive [with farmers adopting] a style of labour relations which had indeed blurred the lines between slavery and other forms of labour subjugation. ${ }^{50}$

We are therefore careful not to treat slaves and Khoisan labour as two separate groups of free and non-free labour, but rather as a combined group, distinct from so-called family-labour. ${ }^{5 \mathrm{I}}$

\section{THE CLOSING OF THE GRAAFF-REINET FRONTIER}

The period under investigation in this paper was characterized by major political and institutional change. Initial European expansion into the

48. Vertress Canby Malherbe, Diversification and Mobility of Khoikhoi Labour in the Eastern Districts of the Cape Colony Prior to the Labour Low of I November I809, unpublished PhD dissertation (Cape Town, I978), p. 66.

49. Ibid.

50. John Edwin Mason, "Fortunate Slaves and Artful Masters: Labour Relations in the Rural Cape Colony During the Era of Emancipation, c.1825-1838”, in Elizabeth Eldridge and Fred Morton (eds) Slavery in South Africa: Captive Labour on the Dutch Frontier (New York, 2009), pp. 74-84.

5. We henceforth refer to this group of slave and Khoe labourers as "non-family" labour to suit the aforementioned theoretical objectives of this paper. 
eastern frontier was followed by decades of instability and hostility between the Europeans, the indigenous Khoisan, and the Xhosa tribes. The expansion of the European settlement on the eastern frontier made it increasingly difficult for the Khoisan to survive as independent pastoral farmers. As early as $\mathrm{I} 773$, Governor Van Plettenberg wrote that in GraaffReinet " $[\ldots]$ there are no Hottentots except those who since several years had hired themselves to the colonists"..$^{2}$ This was likely an exaggeration; nonetheless, in 1775 , in an attempt to further tighten European control over Khoisan labour, the VOC formally instituted the Inboekstelsel - a pass system that severely inhibited the movement of Khoe who did not carry papers showing that they were employed.

Some Khoisan groups resisted European expansion with success. In I 78 , Khoisan had successfully regained control over the land in Sneeuburgen in the north and Camdeboo in the west of Graaf-Reinet, but their success was short-lived. ${ }^{3}$ Instability deepened due to political uncertainty following the decline of the Company and the first British occupation (I795-I802). Countless episodes of violence and conflict littering the final decade of the eighteenth century (indicative of the continued dissatisfaction amongst the Khoe with their former dispossession at the hands of the Boers) ${ }^{54}$ together with mounting dissatisfaction with their working conditions, culminated in the so-called Bushman Wars (I799-I802), which saw an alliance between Xhosa chiefs and Khoe rebels temporarily cripple the frontier economy and dispel many Boers from their farms. ${ }^{55}$

In the early nineteenth century, the English made further attempts to formalize indigenous subjugation through indenturing Khoe labour to European settler farmers by implementing the Caledon Code of I809. It allowed European farmers to keep children of slave fathers and Khoe mothers on their farms until they reached the age of twenty-five. ${ }^{56}$ While the tension between the Europeans and the indigenous populations never completely eroded, the situation gradually stabilized after the second Brit-

52. Robert Ross, Cape of Torments: Slavery and Resistance in South Africa (London, 1983), p. 42. 53. Hermann Giliomee, "The Eastern Frontier, I770-18 I 2", in Richard Elphick and Hermann Giliomee (eds), The Shaping of South African Society, I652-1840 (Middletown, CT, 1989) pp. 439-449.

54. Shula Marks, "Khoisan Resistance to the Dutch in the Seventeenth and Eighteenth Centuries", The Journal of African History, I 3:I (1972), pp. 55-80.

55. William Freund, "The Eastern Frontier of the Cape Colony During the Batavian Period (1803-1806)", The Journal of African History, XIII (1972), pp. 63 I-645.

56. Ross Robert "The Origin of Capitalist Agriculture in the Cape Colony: A Survey", in William Beinart, Peter Delius and Stanley Trapido (eds), Putting a Plough to the Ground, (Johannesburg, 1987), pp. 56-100; N. Penn, The Forgotten Frontier: Colonist and Khoisan on the Cape's Northern Frontier in the I8th Century, (Athens, OH, 2005). 
ish occupation. ${ }^{57}$ By the end of our period of investigation, European settlers had regained control over most of the desirable land in the district, though some Khoisan were permitted grazing rights European controlled land..$^{8}$

The British takeover of the Cape Colony also resulted in a major exogenous shock to the settler population, not least due to the arrival of some 4,000 British settlers to the eastern parts of the Colony, but perhaps more importantly with the ban of slave importation in I 808.59 While the use of slaves was not as widespread in the Graaff-Reinet district as it was in the southwestern Cape, there is evidence suggesting that frontier farmers were nevertheless affected by the increased prices of slaves and the resulting increase in wages for Khoisan labourers. ${ }^{60}$

These changes took place in parallel to the closing of the frontier, in both an economic and administrative sense. Administratively, the establishment of the Uitenhage district in I 804 effectively closed the southern border of Graaff-Reinet ${ }^{6 \mathrm{I}}$ leaving only the northern border open. More importantly, the availability of land was substantially reduced during the period of investigation. We lack systematically recorded data to quantify the closing, but all qualitative evidence suggests that, although land was initially cheap and plentiful, settlers, particularly those with expanding flocks, soon found sufficient grazing lands more difficult obtain. By i 8 I 2, only thirty-nine per cent of married men owned their own farm, and there were no independent Khoisan settlements left in the district. ${ }^{62}$ This does not mean that there was a large group of landless Boers, as many occupied land illegally or rented land from relatives or friends. ${ }^{63}$ Still, the possibility of accessing land cheaply was becoming more limited and, in I 8 I 3 , the loan farm system was replaced by the quitrent system. Coupled with ineffectual administration, the processing of new land claims became increasingly protracted.

In 1824 , the district boundaries were officially extended beyond the Orange River to meet the "insatiable need of an ever-increasing population for more land". ${ }^{6}$ Increased population pressure further limited access to

57. Smith, "From Frontier to Midlands", pp. 54-74.

58. Hermann Giliomee, "Processes in Development of the Southern African Frontier", in Howard Lamar and Leonard Thompson (eds), The Frontier in History: North America and Southern Africa Compared (London, I981) pp. 76-I I9.

59. Neumark, Economic Influences, pp. I I 5-I I6.

60. Johan Fourie and Erik Green, "The Missing People: Accounting for the Productivity of Indigenous Populations in Cape Colonial History", The Journal of African History, 56:2 (2015), pp. 195-2I5.

6r. Smith, "From Frontier to Midlands", pp. 75-8 I.

62. Robert Ross, "The Origin of Capitalist Agriculture"; Penn, The Forgotten Frontier.

63. Smith, "From Frontier to Midlands", pp. I04-I07.

64. Ibid., p. 4. 
grazing lands with sufficient water supply. In I 826, the Landrost of GraaffReinet, Stockenstrom concluded that, "[...] when we speak of occupation, there is not even a stagnant pool that keeps rain water for any length of time which is not regularly occupied, so that of course no spring remains vacant". ${ }^{65}$

The frontier was never entirely closed. Instead, the increased population pressure and shrinking land availability led to the well documented Great Trek of I 834-I 838, as trekboers crossed the Orange River and moved further into the northeast of present day South Africa. ${ }^{66}$

\section{DATA AND METHODS}

Until recently, most research on historical household formation in South Africa has been anecdotal, either coming from traveller accounts, or based on records that are subject to selection problems. ${ }^{67} \mathrm{New}$ research offers a more comprehensive account of the settler fertility transition beginning in the second half of the nineteenth century ${ }^{68}$ But very little is known about pre-transitional household composition in this society and geographically disaggregated micro-level data are needed to better understand the demand for children on frontier farms and how it differed across socio-economic strata.

We combine two newly transcribed datasets. The first is the Opgaafrollen: annual tax censuses collected between I 663 and I 834 by the Dutch East India administration, and after 1795, by the British colonial administration, of all free households of the Colony. Household-level information includes name and surname of the head of the household and spouse, the number of children present in the household, the number of slaves and indigenous Khoisan employed, and several agricultural inputs and outputs, including cattle, sheep, horses, wheat sown, wheat reaped, vines, and wine produced. All males over the age of sixteen were assessed for tax purposes. Unless they headed a household, females were not included. The full series of Opgaafrollen are in the process of being transcribed

65. Papers Relative to the Condition and Treatment of the Native Inhabitants of Southern Africa (Colonial Department, England, I835), p. i 8.

66. Censuses where not taken for I 808 or I 827 . Additionally, I 80 I and I 803 were dropped from the sample due to recording inconsistencies.

67. Leonard Guelke, "The Anatomy of a Colonial Settler Population: Cape Colony 1657-1750", The International Journal of African Historical Studies, 2 I:3 (1988), pp. 453-473; Charles Simkins and Elizabeth van Heyningen, "Fertility, Mortality, and Migration in the Cape Colony, I89I1904”, The International Journal of African Historical Studies, 22: ( (1989), pp. 79-I I I.

68. Jeanne Cilliers and Martine Mariotti, "The Shaping of a Settler Fertility Transition: Eighteenth and Nineteenth Century South African Demographic History Reconsidered", Lund Papers in Economic History: Population Economics; No. 173, (Lund: Department of Economic History, Lund University, 2018). 
and the household contained therein, identified and linked across years using a probabilistic record linkage strategy to create an annual panel of household production across more than a century. ${ }^{69}$

We use a sub-sample of these censuses for the Graaff-Reinet district covering the period I798-I828. The panel contains 35, I99 observations over twenty-eight years, ${ }^{70}$ comprised of 10,162 unique households. But, since these data do not contain information on birth dates (crucial in controlling for, and distinguish between, age, period, and cohort effects) or death dates (crucial for controlling for lifecycle wealth effects), we supplement these data with individual-level demographic data for the household head from the South African Families Database (SAF). Obtained from the Genealogical Institute of South Africa (GISA), these data contain information on all settler families from I652 to approximately I 830 as well as those of new progenitors of settler families up to $\mathrm{I} 867$. The probabilistic record linkage strategy that was used to identify and match households over time to create the CGHP is applied to identify and match heads of households across these two sources with a match rate of between 40 and 60 percent annually. ${ }^{71}$

Information on household assets and production in the Opgaafrollen was used to estimate household wealth. ${ }^{72}$ We choose to estimate separately what we will henceforth refer to as "asset wealth" and "capital wealth". We take the asset component of wealth as the total real value of livestock, by multiplying the number of small livestock (sheep, cattle and goats) owned in a given census year by the estimated value thereof using a series of livestock prices from probate inventories (MOOC 8 Series, TANAP 20I2). ${ }^{73}$ In order to determine the capital component of wealth, we sum all productive assets owned by an individual in a given census year. ${ }^{74}$ Through the selection of variables, we have tried to identify those elements necessary to

69. Auke Rijpma et al., "Record Linkage in the Cape of Good Hope Panel", Lund Papers in Economic History: Population Economics; No. 172, (Lund: Department of Economic History, Lund University, 2018).

70. Censuses where not conducted in 1808 or 1827 .

71. Ibid., p. 20.

72. While is it common for self-reported tax records to underestimate the value of household wealth, we are less concerned with this being a potential source of bias in our sample, since census enumerators personally visited all of the farms in a district to take account of how much these households owned and produced.

73. Here, we were only able to use assets for which the relevant price series were available: cattle, sheep, and goats. The exchange rate between rixdollars and pounds was adjusted as required following Markus A. Denzel, Handbook of World Exchange Rates, I590-19I4 (Farnham, 2010) and for years where no information was available, the assumption was made that the price and or exchange rate remained the same as the previous period.

74. Principal component analysis was also used to estimate a capital wealth score, but the use of nominal capital yielded similar results and their coefficients were simpler to interpret. 
Table I. Characteristics of frontier farms.

\begin{tabular}{|c|c|c|c|c|c|}
\hline Variable & Average & Std. Dev & Min & $\operatorname{Max}$ & Price \\
\hline \multicolumn{6}{|l|}{ Human capital } \\
\hline Settler children & 2.3 & 2.6 & 0 & 14 & $\mathrm{n} / \mathrm{a}$ \\
\hline Khoi & 3.3 & 6.3 & 0 & 78 & $\mathrm{n} / \mathrm{a}$ \\
\hline Slaves & 1.1 & 2.9 & 0 & 61 & 266.3 \\
\hline \multicolumn{6}{|l|}{ Livestock } \\
\hline Sheep & 495.1 & 758.7 & 0 & 14121 & 0.3 \\
\hline Cattle & 44.7 & 72.7 & 0 & 2813 & 0.5 \\
\hline Goats & 32.0 & 84.3 & 0 & 4326 & 0.5 \\
\hline Donkeys & $<1$ & 3.6 & 0 & 400 & $\mathrm{n} / \mathrm{a}$ \\
\hline Pigs & $<1$ & 1.1 & 0 & 120 & $\mathrm{n} / \mathrm{a}$ \\
\hline \multicolumn{6}{|l|}{ Capital } \\
\hline Horses & 5.2 & 13.4 & 0 & 1866 & 11.9 \\
\hline Horse wagons & 1.5 & 2.3 & 0 & 31 & $\mathrm{n} / \mathrm{a}$ \\
\hline Wagons & 0.6 & 1.2 & 0 & 186 & $\mathrm{n} / \mathrm{a}$ \\
\hline Carts & 0.0 & 0.1 & 0 & 10 & $\mathrm{n} / \mathrm{a}$ \\
\hline Oxen & 6.7 & 10.1 & 0 & 240 & $\mathrm{n} / \mathrm{a}$ \\
\hline Wheat sown & $<1$ & 1.0 & 0 & 62.875 & $\mathrm{n} / \mathrm{a}$ \\
\hline Barley sown & $<1$ & 0.6 & 0 & 39 & $\mathrm{n} / \mathrm{a}$ \\
\hline Rye sown & $<1$ & 0.0 & 0 & 4 & $\mathrm{n} / \mathrm{a}$ \\
\hline Oats sown & $<1$ & 1.2 & 0 & 102 & $\mathrm{n} / \mathrm{a}$ \\
\hline \multicolumn{6}{|l|}{ Output } \\
\hline Wheat reaped & 5.4 & 21.8 & 0 & 1232 & $\mathrm{n} / \mathrm{a}$ \\
\hline Barley reaped & 3.0 & 16.1 & 0 & 1150 & $\mathrm{n} / \mathrm{a}$ \\
\hline Rye reaped & $<1$ & 0.6 & 0 & 67 & $\mathrm{n} / \mathrm{a}$ \\
\hline Oats reaped & $<1$ & 0.6 & 0 & 80 & $\mathrm{n} / \mathrm{a}$ \\
\hline
\end{tabular}

Notes: Grains sown in a given year are reported in muids, a South African measure of dry capacity equivalent to about Iog litres.

capture improved capacity to produce a surplus for the market. These include number of horse wagons, horses, oxen, ox wagons and carts. ${ }^{75}$

\section{RESULTS}

It is useful to begin with an examination of the typical household structure and economic circumstances of the population in question. Table i shows the characteristics of an average farming household in our population. On average, frontier farms housed two adult settlers (typically a husband and a wife), and two settler children in a given census year. We can see that rearing stock was clearly the dominant economic activity on frontier farms, with the average farm accommodating over 500 heads of sheep and around fifty heads of cattle. 


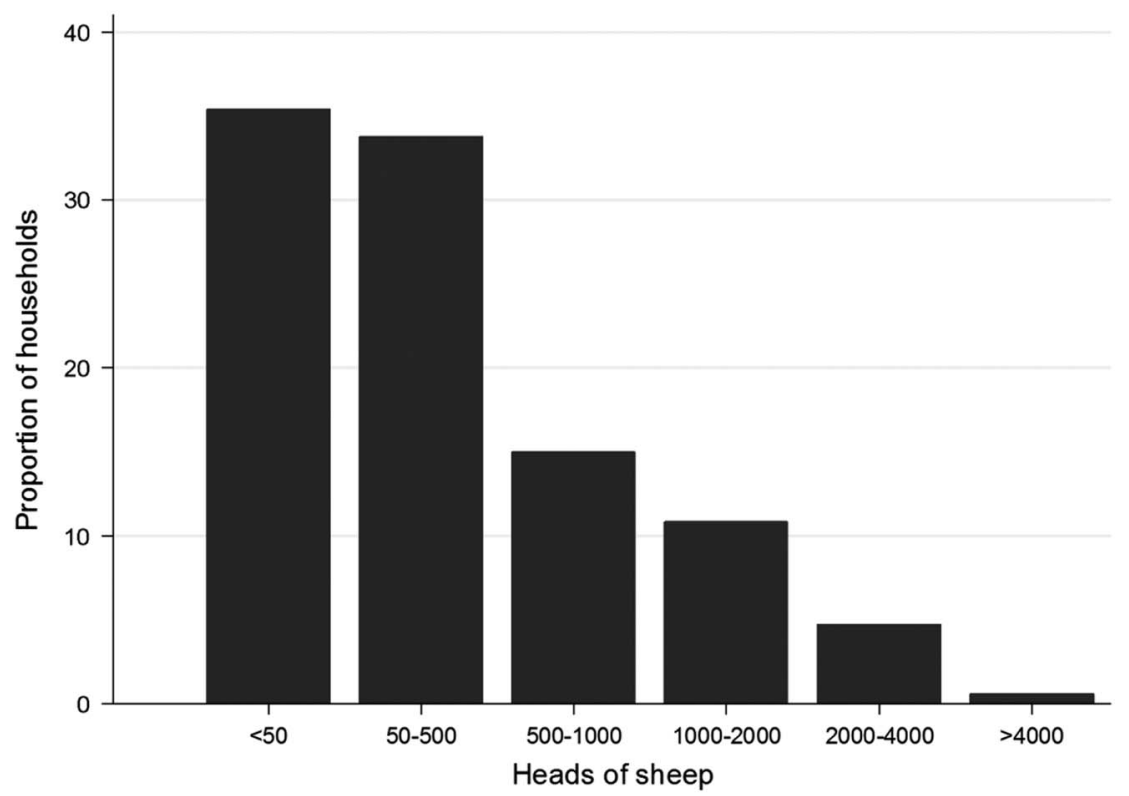

Figure 3. Proportion of settler households owning sheep, Graaff-Reinet district, I798-1828.

It has been suggested, however, that a man with just fifty sheep or thirty cattle would not have been in a position to support himself, let alone his family. ${ }^{76}$ If we consider the proportion of households owning less than fifty sheep or thirty cattle in a given year, shown in Figures 3 and 4 , we can indeed see that many stock famers were barely making ends meet. It is also important to the degree of variation in both sheep and cattle ownership; one particularly wealthy farmer owned some i 2,000 heads of sheep, while another had 2,8I 3 heads of cattle in a given year. But these extremely wealthy individuals appear to be a minority. On average, households owned around six horses and nine oxen, sufficient to pull their carts and wagons to market and to drive their ploughs. Graaff-Reinet was not known for being a grain-producing district, which is evidenced by the low volume of wheat, barley, oats, and rye sown in any given year. That is not to say that farmers did not engage in these activities, if only for subsistence.

From Figure 5, we can see that the average number of settler children in frontier households steadily increased over the period of frontier closure in Graaff-Reinet. From Figure 6, we can see that the presence of children in frontier households has a clearly positive association with wealth if we 


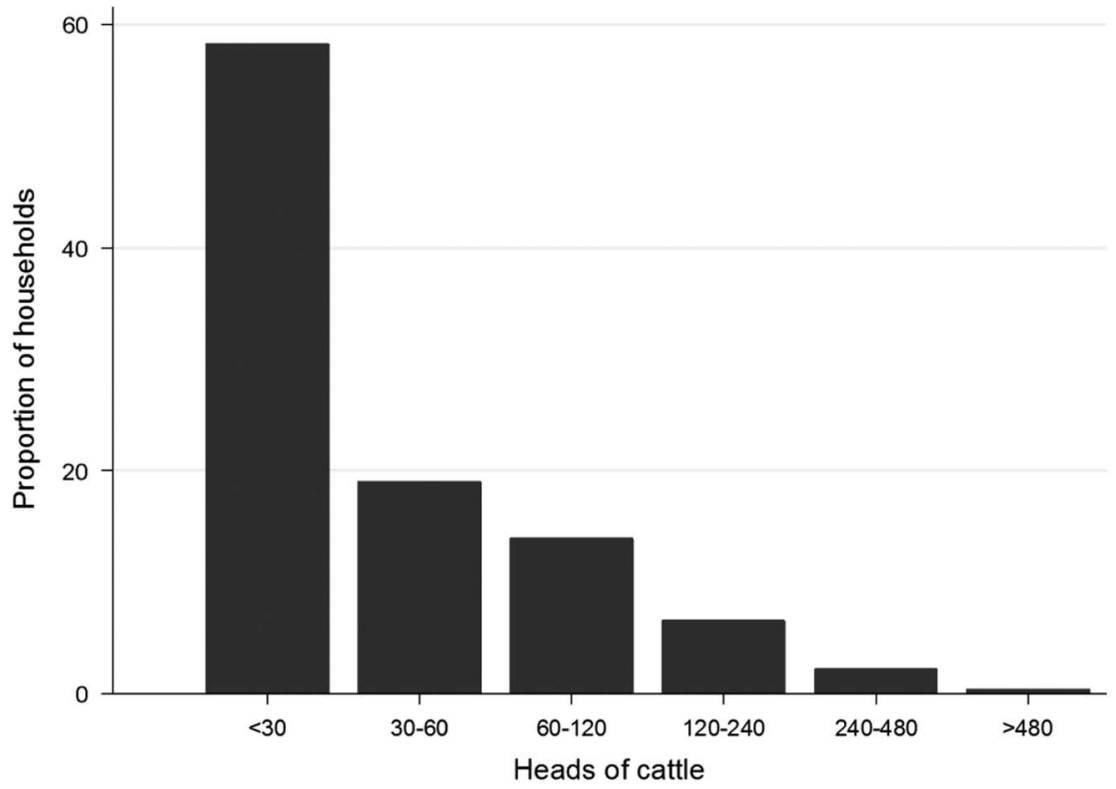

Figure 4. Proportion of households owning cattle, Graaff-Reinet district, I798-I 828.

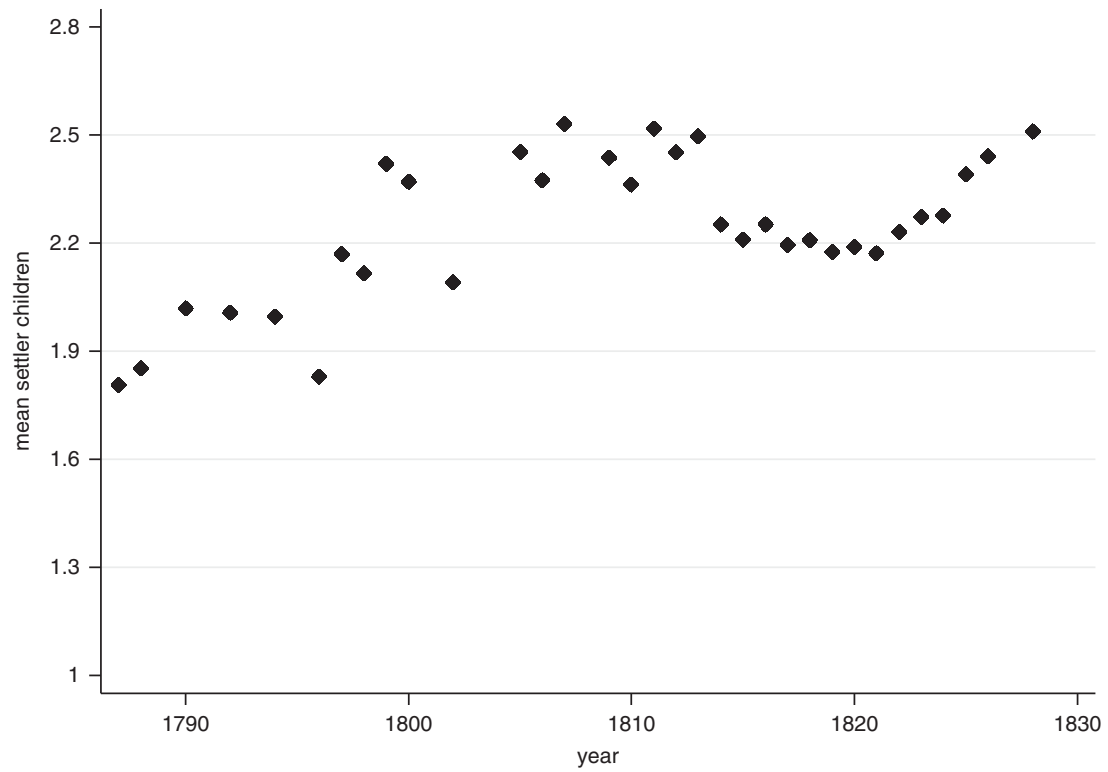

Figure 5. Average number of settler children present in settler households, Graaff-Reinet district, I $798-\mathrm{I} 828$. 


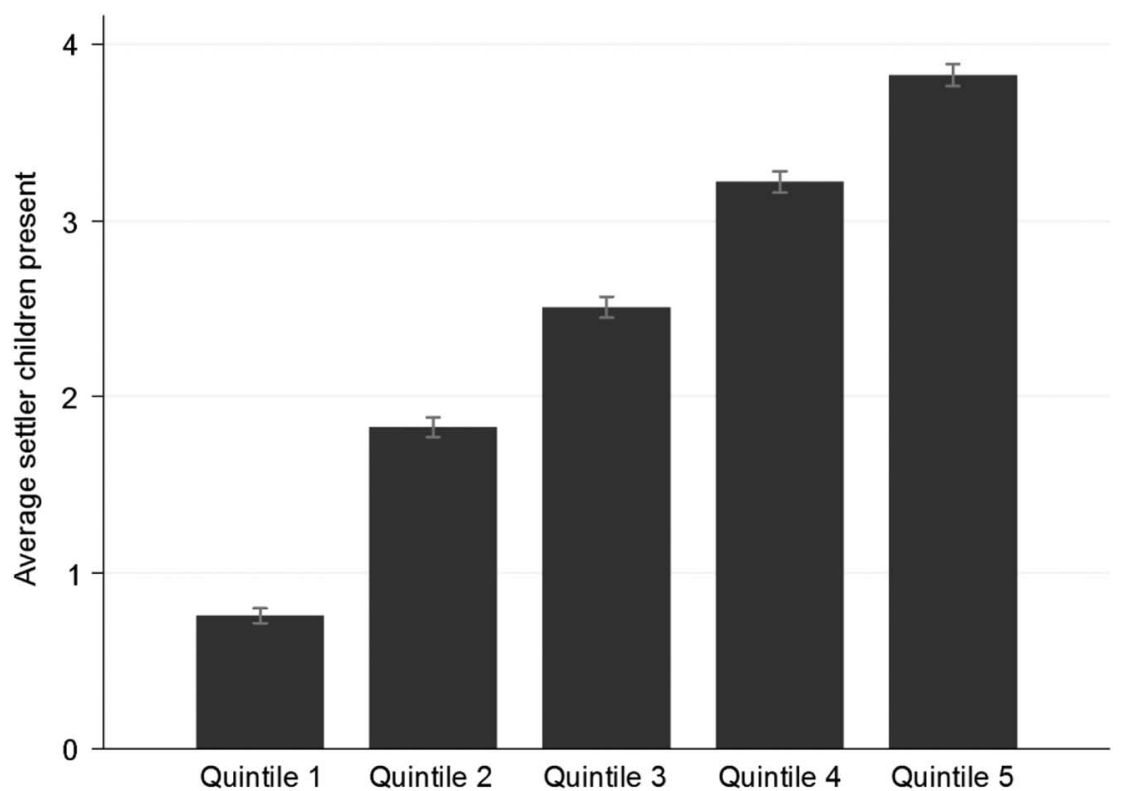

Figure 6. Average number of settler children present in settler households by real wealth quintile, Graaff-Reinet district, I798-1 828 .

Notes: The number of observations in quintiles $I-5$ are $7693,6546,6900,7042$, and 7018 respectively.

consider this population across wealth quintiles, before taking into account any variation over time.

Given the large variation in livestock and capital holdings described it is critical that we account for the high degree of inequality in this society. We begin by estimating a Gini coefficient for every year in our panel, the results of which are shown in Figure 7. In line with findings for the Cape Colony in general, ${ }^{77}$ these results confirm that the farming population of Graaff-Reinet was indeed highly unequal, with the Gini coefficient consistently above 0.6 .

Further evidence of a small but very wealthy elite is presented in Figure 8, which shows that the average total value of assets owned by the wealthiest five per cent was ten times more than the rest of the population. Returning, then, to the relationship between wealth and family size, we find that the wealthiest five per cent had a family size sixty per cent larger than the remaining ninety-five per cent of the population, as shown in Figure 9. 


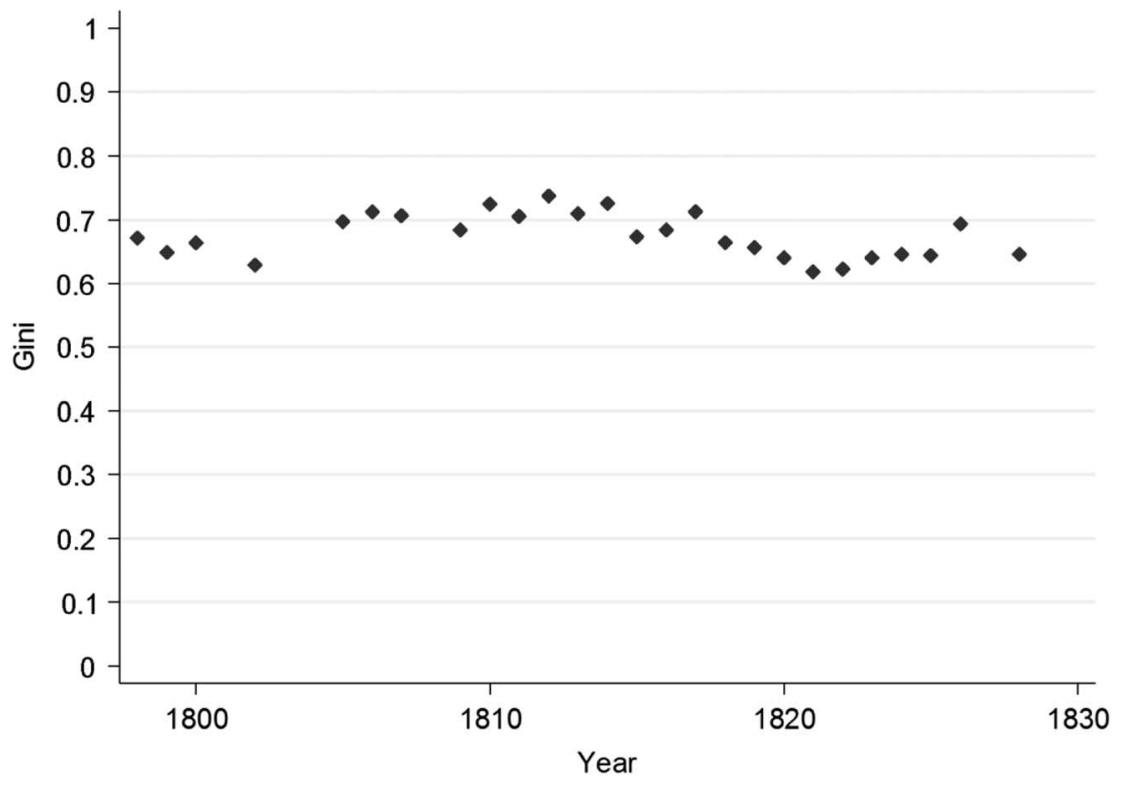

Figure 7. Annual Gini coefficient, Graaff-Reinet district, I798-I828.

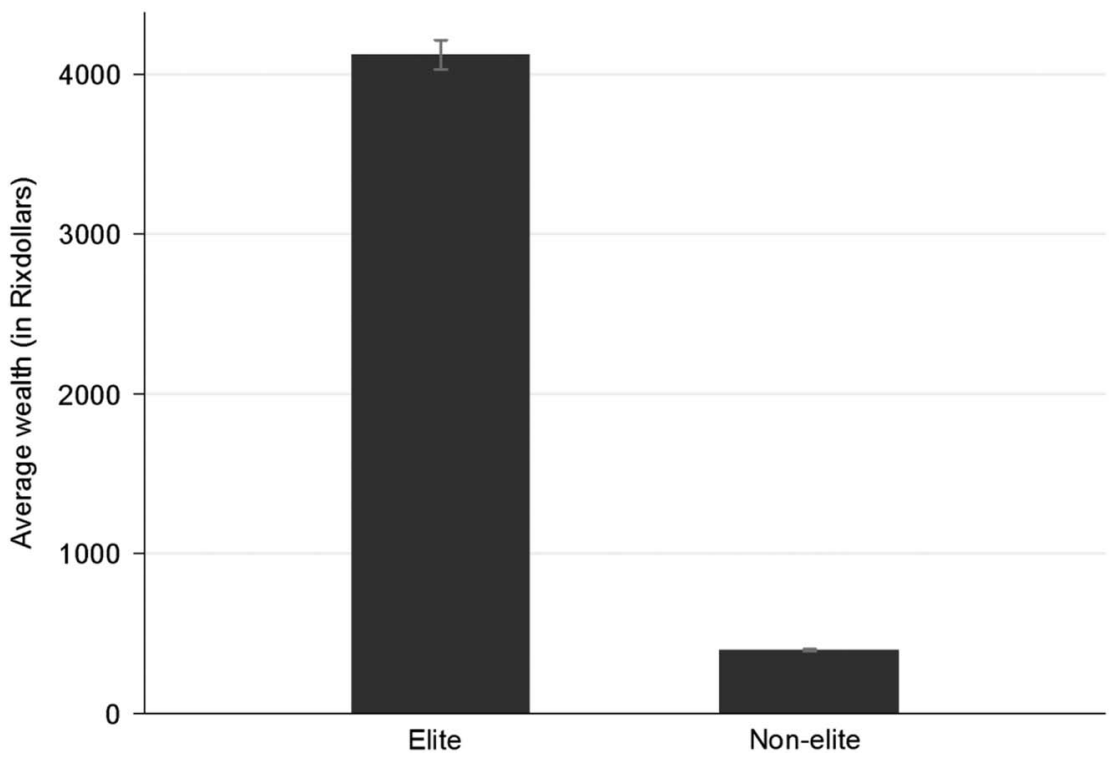

Figure 8. Average real wealth (in Rixdollars) for the elite (wealthiest top 5 per cent of the sample) versus non-elite (bottom 95 per cent of the sample), with 95 per cent confidence bars. 


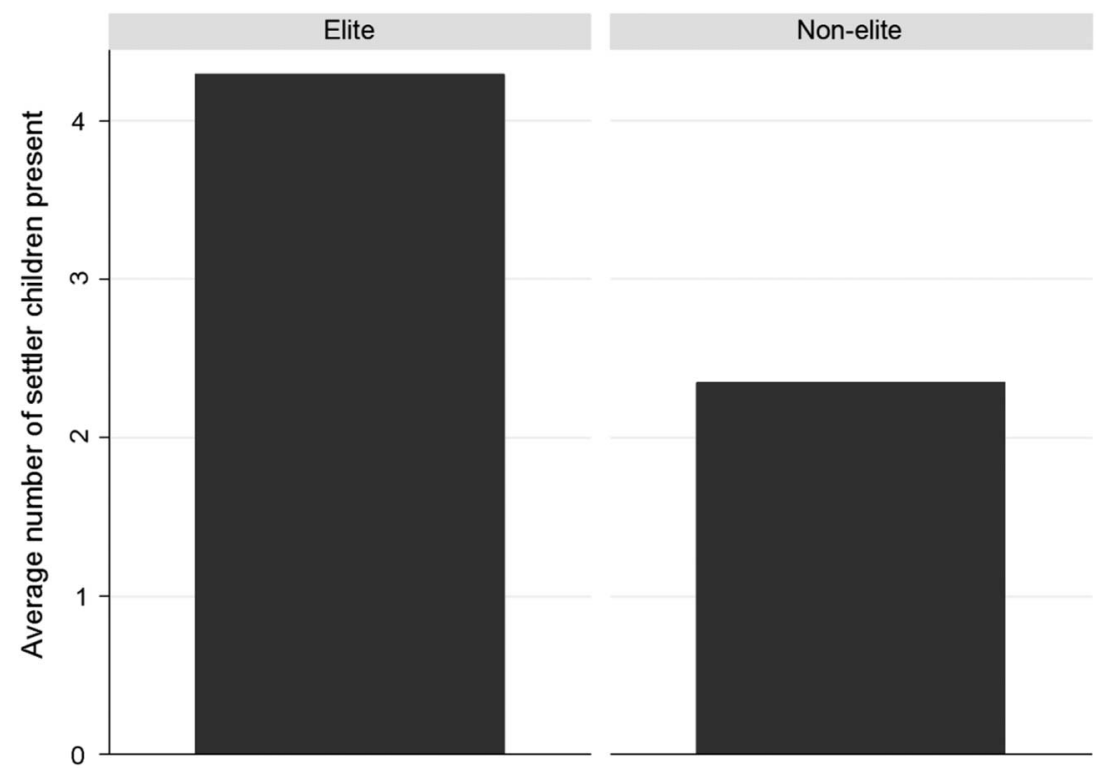

Figure 9. Average number of settler children present in the households of the elite (wealthiest top s per cent of the sample) versus the non-elite (bottom 95 per cent of the sample).

It is critical, therefore, to take into account these stark societal inequalities when characterizing economic and social behaviour over time. We are able to control for this variation in wealth using a simple regression framework in which we estimate the association between capital and livestock wealth, non-family labour, and settler children present for all households over time. ${ }^{78}$ Figure Io summarizes the coefficients from our first model, which has as the dependent variable, the number of settler children present in a household. We find a positive association between livestock wealth, capital wealth, and the presence of non-family labourers in the household, respectively, with the presence of settler children in frontier households. ${ }^{79}$

We also want to establish how this relationship changed over time in order to determine the effect of a closing frontier. We find that, over time, the presence of settler children in frontier households is negatively associated with wealth, i.e. while in absolute terms the wealthiest households report more settler children present, they begin to reduce this over time. This reduction could be the

78. Details about the models we have selected together with the full output from the regressions can be found in the empirical appendix.

79. Given that the prices we use to measure the real value of livestock wealth come from auction rolls, they could be biased causing us to underestimate this relationship. However, all models were found to be robust to the inclusion of either the real or nominal value of livestock and we therefore choose to present only nominal values going forward. 


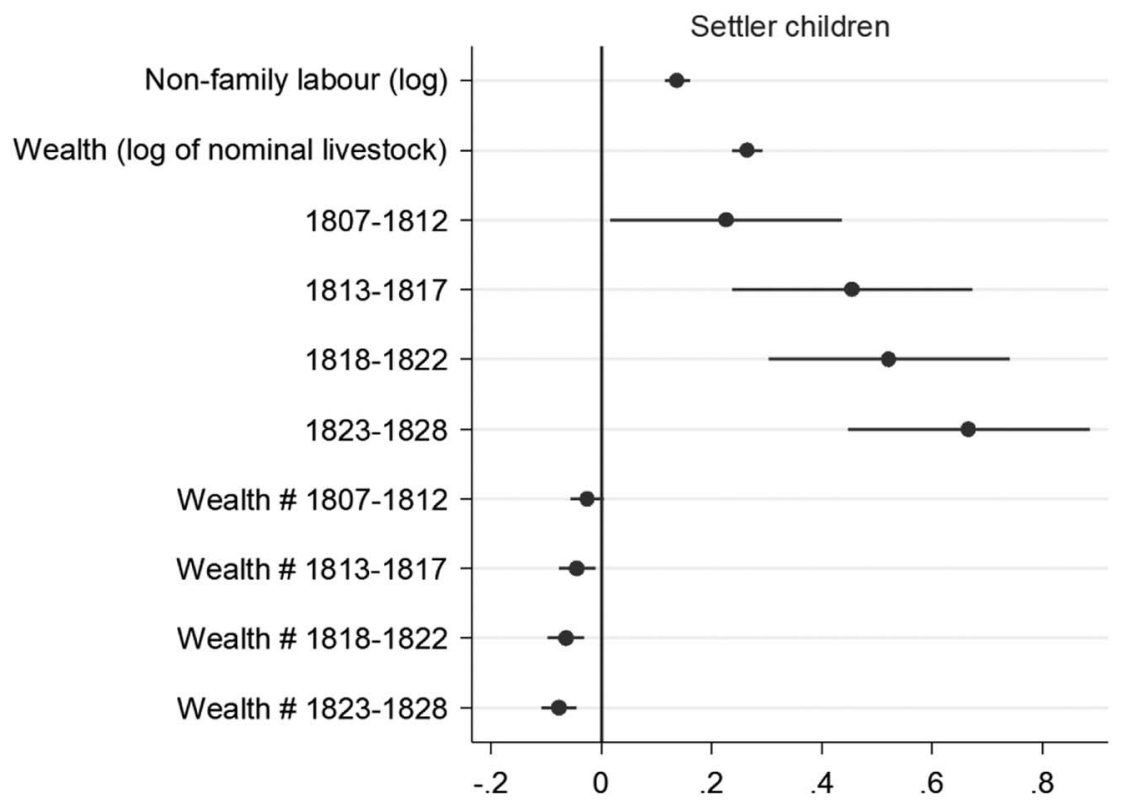

Figure ı०. Summary of coefficients from a negative binomial regression with dependent variable: settler children.

Notes: All coefficients were significant at the 95 per cent level. Figure corresponds to model 2 in Table Ar.

result of conscious fertility limitation within this group, or a feature of higher social mobility for the children of wealthy farmers, i.e. children of the wealthy may have been more likely to pursue opportunities outside the family farm.

However, the strong positive association of wealth (in its various forms) and children present might be explained if there is a high correlation between asset wealth and the age of the household head, if we believe that individuals typically accumulate assets and children over the course of their lives. Using a sub-sample of households matched to the SAF database, for which we can determine the age of the head of the household, we can deduce whether such effects are present as well as control for them in our models. From figures I I, I 2, and I 3, we can clearly see that there are strong lifecycle effects with respect to wealth and children.

Note that, since the size of the linked sample is much smaller than the full sample, resulting from the fact that not all household heads were able to be identified and matched to the genealogical registers, we limit the use of the linked sample to checks on model robustness. However, even with reduced sample size, the magnitude and significance of the coefficients of interest remain, i.e. controlling for the positive effects of the age of the household head on the number of children present and overall household wealth, an 
Wealth, Labour and Household Composition on the South African Frontier 263

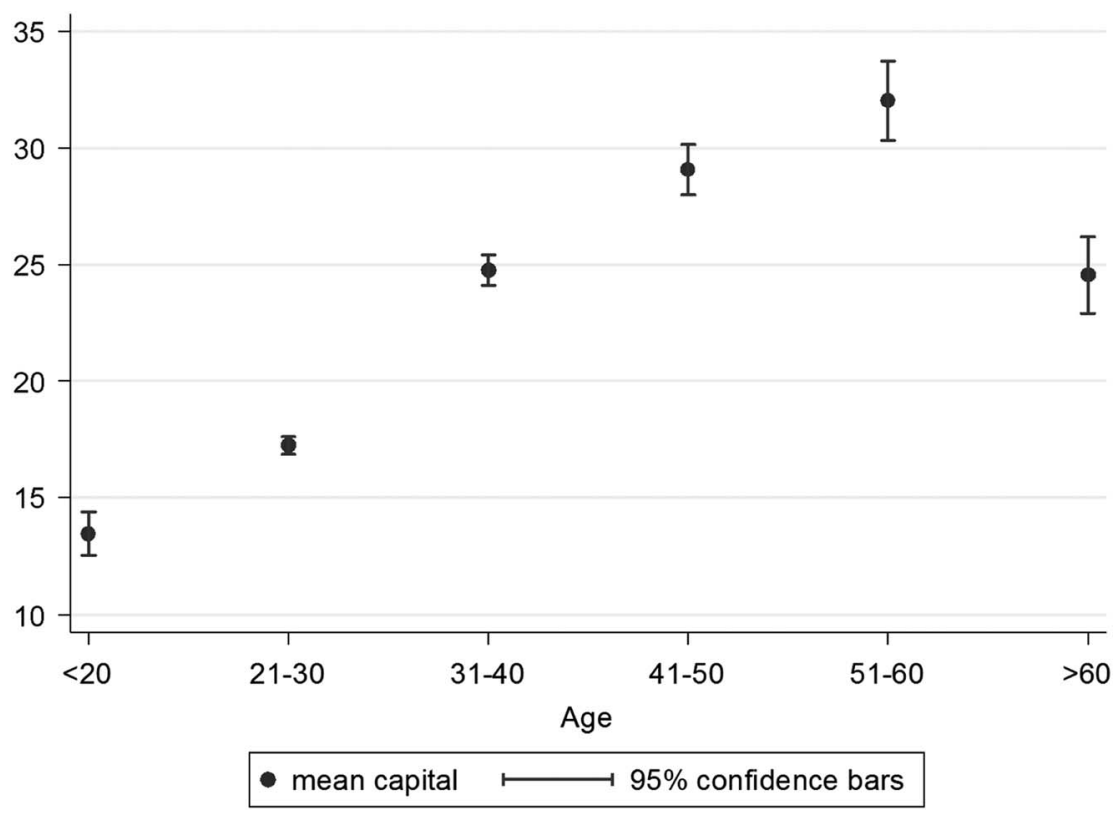

Figure I r. Mean capital by household head age, with 95 per cent confidence bars.

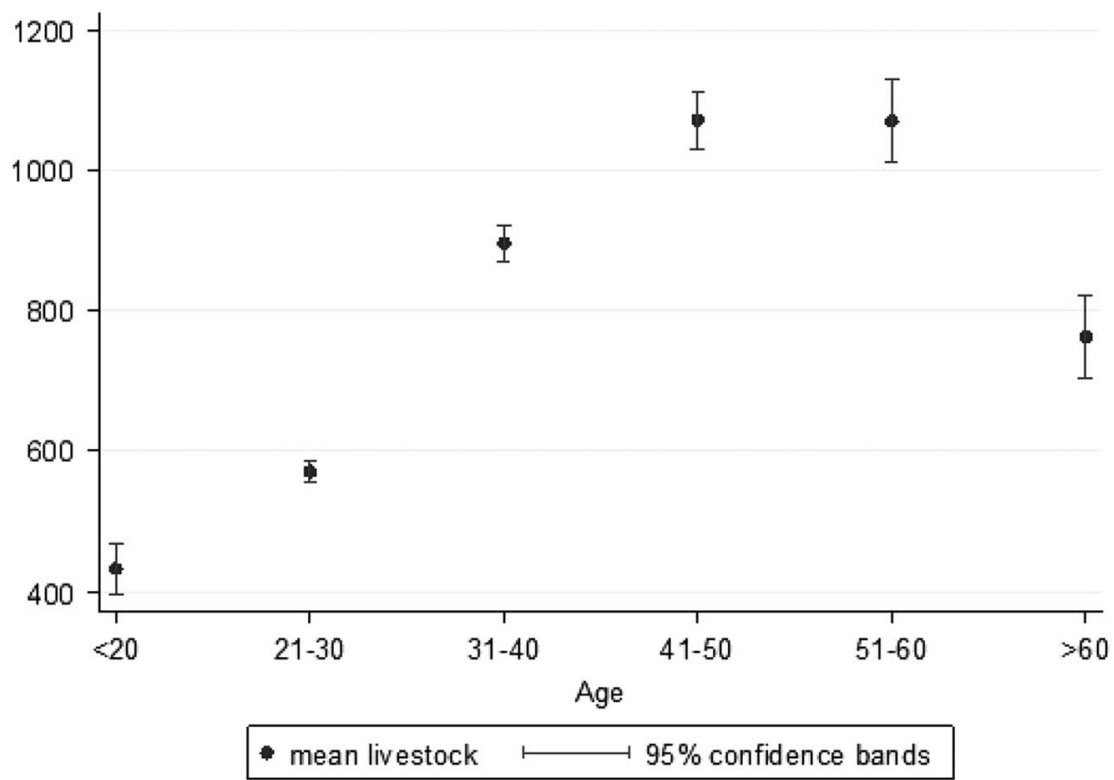

Figure I2. Mean wealth (livestock) by household head age, with 95 per cent confidence bars. 


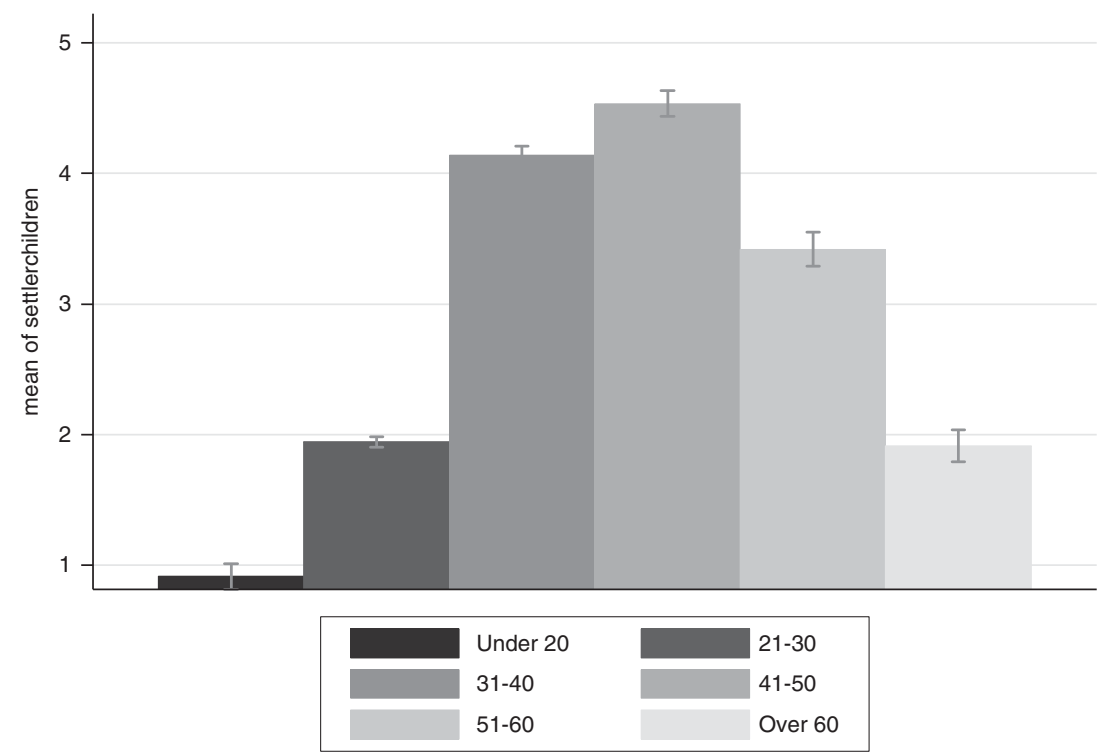

Figure I 3 . Mean settler children by household head age, with 95 per cent confidence bars.

independent positive correlation between livestock wealth, capital wealth, and the presence of slave and Khoe labour remain significant.

Next, we want to see how different wealth groups substitute between family and non-family labour. For this, we consider the ratio of children to non-family labour (slaves plus Khoe) present on the farm in a given census year. A higher ratio is indicative of more non-family labour being employed relative to family labour. Figure i4 summarizes the results of our model, which shows a positive association of both capital wealth and livestock wealth with the use of non-family labour, suggesting that wealthier households could indeed afford to own more slaves and employ more Khoe than poorer households. We can also see that the use of non-family labour was declining over time. The reduction in the ratio of family to non-family labour over time for the wealthy is also larger than for the poor, due to the fact that while the use of both family and non-family labour was decreasing for this group, the relative decline of non-family labour was larger.

But if we believe that frontier households desired to maintain output amidst frontier closure, we ought to question why the wealthy chose to reduce both family and non-family labour. We therefore consider the ratio of capital to labour over time - a larger ratio being indicative of relative capital intensification. From Figure I 5 , we can see that for the population in general, we find evidence that the wealthy remained more labour intensive than the poor in absolute terms, but that, over time, chose to invest in more carts, wagons, oxen, horses, and breeding animals so as to allow themselves 


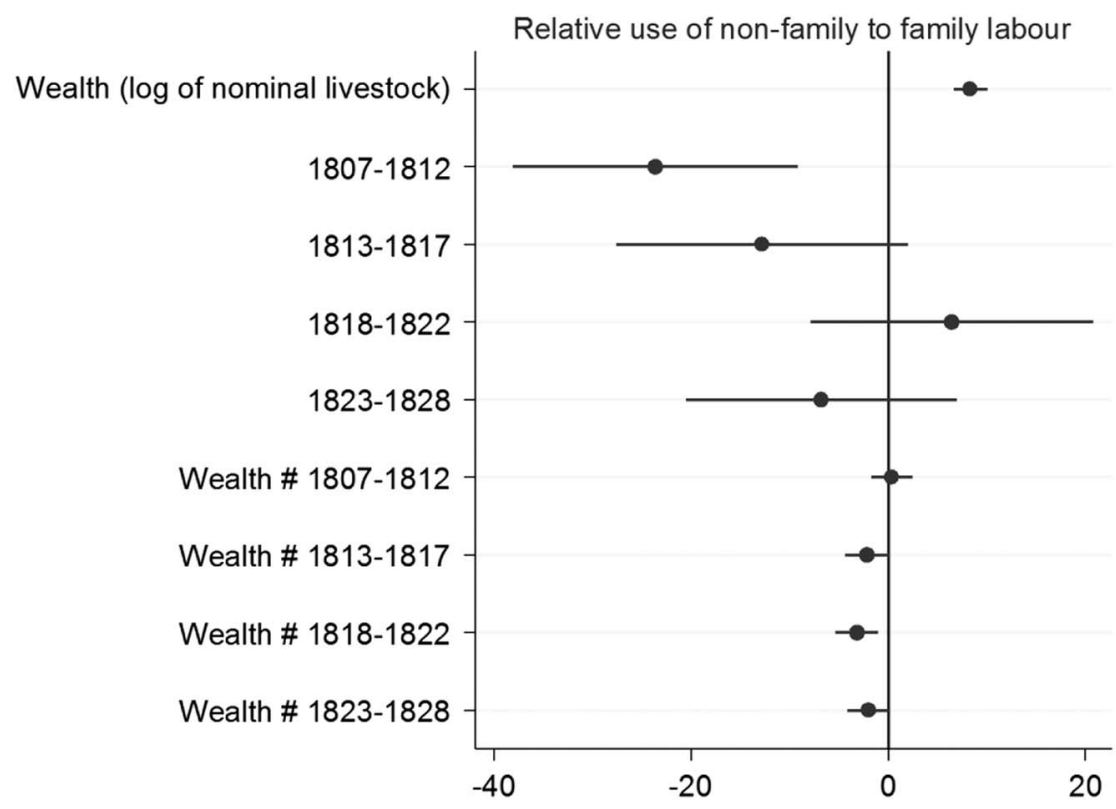

Figure I4. Summary of coefficients from an ordinary least squares regression with dependent variable: family to non-family labour ratio.

Notes: Figure corresponds to model 4 in Table Ar.

greater productive capacity and better market access relative to labour, to a greater extent than the poor.

\section{CONCLUDING DISCUSSION}

Since the I960s, studies have found that fertility declines in the nineteenthcentury Western world cannot be fully understood without considering the population dynamics in the rural areas. Focusing on the rural US and Canada, scholars found that fertility levels systematically differed between newly established frontier regions and older ones. Fertility levels were significantly lower in the established and more densely populated areas compared to the less densely populated frontier regions. Although a lack of data prevents more precise empirical testing, these systematic differences in fertility levels have commonly been explained by the land-labour hypothesis. Fertility levels were higher in frontier regions either because the demand for child labour was larger and/or the cost of having children was lower.

In this paper, we contribute to the debate by analysing the relationship between land availability and children present in settler farming households in the Graaff-Reinet district at the eastern frontier of Cape Colony. Different from the frontier literature, we find for the Graaff-Reient district that the closing of the frontier was associated with an increased presence of children. 


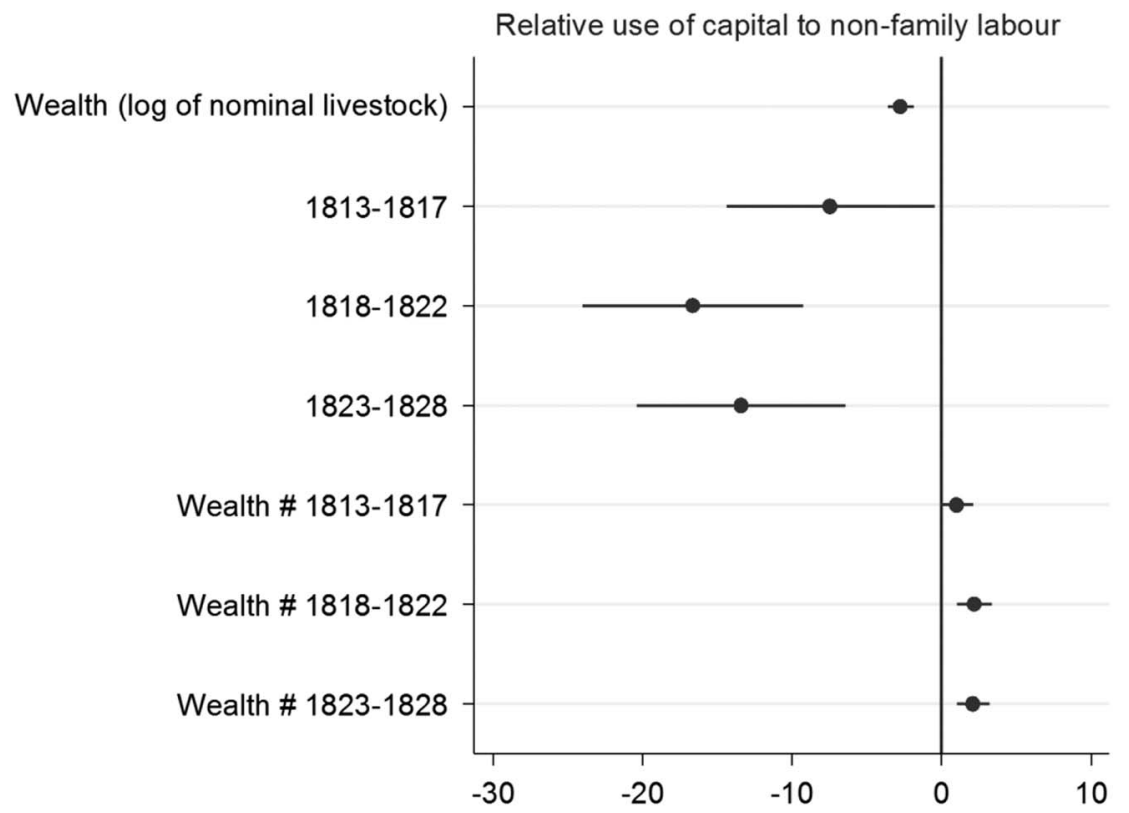

Figure is. Summary of coefficients from an ordinary least squares regression with dependent variable: capital to labour ratio.

Notes: Figure corresponds to model 6 in Table Ar.

We identify two weaknesses in the frontier literature: the failure to account for wealth inequalities and the failure to distinguish between family and non-family labour. Rural populations will respond differently to shrinking land availability depending on their wealth because the latter determines the available adaption strategies. A rich farm household may respond to diminishing land availability by substituting labour for capital, while this option is simply not available to a poor household. Wealth inequality in Graaff-Reinet was considerable and the vast majority of frontier farmers struggled to subsist. So, while a small minority did indeed respond to shrinking land availability by developing more capital-intensive methods of production, the poor did not. We find that the poorer farmers responded by increasing their relative use of family labour. This strategy makes economic sense if we - different from the frontier literature - make a clear distinction between family and non-family labour. The employment of non-family labour is dependent on the marginal productivity of labour. This is not the case for family labour as shown by development economists, agrarian historians, and economic historians. On the contrary, in preindustrial societies, farmers will respond to shrinking land availability by adding more labour to land despite decreasing marginal productivity of labour. This Boserupian path was what the majority of the Graaff-Reinet 
population followed. Lacking alternative means to using family labour, they intensified labour use in light of shrinking land availability, which created a demand for having more children.

This leads us to conclude that, for the poor, we see a negative correlation between land availability and labour demand. The reason why the GraaffReinet households experienced, on average, an increased presence of settler children in the midst of a closing frontier, is that a large majority of the population consisted of the poor. In that regard, our study does not necessarily contradict previous findings. It may very well be that farmers in nineteenth-century US and Canada were, on average, wealthy enough to respond to shrinking land availability by employing more capital intensive farming methods. The implications of our findings are, however, that the positive relationship between fertility and land availability may not be universal, as previously thought, but largely dependent on levels and distribution of wealth among the rural inhabitants.

\section{EMPIRICAL APPENDIX}

To model the effects of wealth and the use of non-family labour on the presence of settler children in frontier households, negative binomial distribution models were selected over ordinary least-squares as they are designed to analyse count data and account for the fact that the number of children in a family is non-negative. They also account for over-dispersion (where the mean is greater than the variance) common in fertility data, by treating dispersion as a parameter to be estimated from the data. ${ }^{80}$ Over-dispersion in our sample results from excess zeros, due to many households being observed before childbearing begins. We run the following specification:

$$
y_{i t}=\alpha+\beta_{\mathrm{I}} \ln \left(\text { Labour }_{i t}\right)+\beta_{2} \ln \left(\text { Wealth }_{i t}\right)+\beta_{3}(\text { Period })+\epsilon_{i t}
$$

where $y_{i t}$ is the number of settler children present in household $i$ in year $t . \beta_{1}$, and $\beta_{2}$ represent the effects of the log of non-family labour, and nominal livestock wealth, respectively, and are our outcome variables of interest. $\beta_{3}$ represents the effects of the categorical variables representing five time periods from I 789 -I 828 . $\varepsilon_{i t}$ represents unobservable determinants that vary across time and individuals. We cluster at the household level to obtain robust standard errors.

In specification 2, wealth and period are interacted to model the effect over time:

$$
\begin{aligned}
y_{i t}= & \alpha+\beta_{\mathrm{I}} \ln \left(\text { Labour }_{i t}\right)+\beta_{2} \ln \left(\text { Wealth }_{i t}\right)+\beta_{3}(\text { Period }) \\
& +\beta_{4}\left(\ln \left(\text { Wealth }_{i t} * \text { Period }\right)+\epsilon_{i t}\right.
\end{aligned}
$$

80. Weiren Wang and Felix Famoye, "Modeling Household Fertility Decisions with Generalized Poisson Regression”, Journal of Population Economics, I0:3 (1997), pp. 273-283, 284. 
To model the relative use of non-family labour in frontier households, we use OLS with the following specification:

$$
\frac{y_{i t}}{L_{i t}}=\alpha+\beta_{\mathrm{I}} \ln \left(\text { Wealth }_{i t}\right)+\beta_{2}(\text { Period })+\epsilon_{i t}
$$

Where $\frac{y_{i t}}{L_{i t}}$ represents the ratio of family to non-family labour in household $i$ in year $t$. To account for the fact that such a ratio may be unstable if the denominators are small, or indeterminate if the denominators are ever $\mathrm{o}$, we use instead, the following expression to summarize the relative change of non-family labour with respect to family labour: ${ }^{8 \mathrm{r}}$

$$
\text { I00* }\left(\left(y_{i t} /\left(y_{i t}+L_{i t}\right)\right)-\left(L_{i t} /\left(y_{i t}+L_{i t}\right)\right)\right)
$$

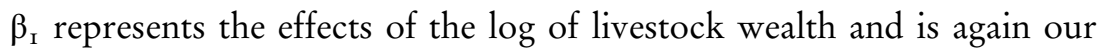
main variable of interest. In specification 4 , wealth and period are again interacted to model the effect over time:

$$
\frac{y_{i t}}{L_{i t}}=\alpha+\beta_{\mathrm{I}} \ln \left(\text { Wealth }_{i t}\right)+\beta_{2}(\text { Period })+\beta_{3}\left(\ln (\text { Wealth })_{i t} * \text { Period }\right)+\epsilon_{i t}
$$

Lastly, to model relative labour and capital intensification as it relates to household wealth we use OLS with the following specification:

$$
\frac{L_{i t}}{C_{i t}}=\beta_{\mathrm{I}} \ln \left(\text { Wealth }_{i t}\right)+\beta_{2}(\text { Period })+\epsilon_{i t}
$$

Where $\frac{L_{i t}}{C_{i t}}$ represents the ratio of labour to capital in household $i$ in year $t$, again estimated as:

$$
\text { I00* }\left(\left(L_{i t} /\left(L_{i t}+C_{i t}\right)\right)-\left(C_{i t} /\left(L_{i t}+C_{i t}\right)\right)\right)
$$

In specification 6, wealth and period are again interacted to model the effect over time:

$$
\frac{L_{i t}}{C_{i t}}=\beta_{\mathrm{I}} \ln \left(\text { Wealth }_{i t}\right)+\beta_{2}(\text { Period })+\beta_{3}\left(\ln (\text { Wealth })_{i t} * \text { Period }\right)+\epsilon_{i t}
$$

For the SAF linked sample we following the same specification as equation (I), with the inclusion of $\theta$ and $\Phi$ which represents the potentially nonlinear effects of age $\left(a_{i t}\right)$ and age squared $\left(a_{i t}\right)^{2}$

$$
\begin{aligned}
y_{i t}= & \alpha+\beta_{1} \ln \left(\text { Labour }_{i t}\right)+\beta_{2} \ln \left(\text { Wealt }_{i t}\right)+\beta_{3}(\text { Period }) \\
& +\beta_{4}\left(\ln (\text { Wealth })_{i t} * \text { Period }\right)+\theta\left(a_{i t}\right)+\Phi\left(a_{i t}^{2}\right)+\epsilon_{i t}
\end{aligned}
$$

8I. Nicholas J Cox. "Stata: Creating Variables That Are 'Plurality' Measures", available at: https://www.stata.com/support/faqs/data-management/plurality/measures/; last accessed $3 \mathrm{I}$ May 2018. 
Table Ar. Estimates from negative binomial and OLS models.

\begin{tabular}{|c|c|c|c|c|c|c|}
\hline \multirow[b]{3}{*}{ Specification } & \multicolumn{2}{|c|}{ Settler children } & \multicolumn{2}{|c|}{ Labour ratio } & \multicolumn{2}{|c|}{ Capital ratio } \\
\hline & \multicolumn{2}{|c|}{$N B R E G$} & \multicolumn{2}{|c|}{$O L S$} & \multicolumn{2}{|c|}{ OLS } \\
\hline & I & II & III & IV & $\mathrm{V}$ & VI \\
\hline Non-family labour & $0.143 * \cdots$ & $0.137 * * \%$ & $\mathrm{n} / \mathrm{a}$ & & $\mathrm{n} / \mathrm{a}$ & $\mathrm{n} / \mathrm{a}$ \\
\hline Livestock wealth & $0.213 * *$ & $0.264 * * *$ & $6.653 \% \div$ & $8.354 \% \div \%$ & $-1.215 * \%$ & $-2.707 * * *$ \\
\hline $1798-1806$ & ref. & ref. & ref. & ref. & $\mathrm{n} / \mathrm{a}$ & $\mathrm{n} / \mathrm{a}$ \\
\hline 1807-1812 & $0.0655 \%$ & $0.226 * *$ & $-20.96 * \%$ & $-23.64 * \cdots *$ & ref. & ref. \\
\hline $1813-1817$ & $0.170 * * *$ & $0.455 * \cdots$ & $-25.65 \%$ & $-12.77 *$ & -1.227 & $-7.428 *$ \\
\hline $1818-1822$ & $0.117 * * \%$ & $0.522 * *$ & $-12.08 \% *$ & 6.473 & $-4.562 * \%$ & $-16.63 * * *$ \\
\hline $1823-1828$ & $0.187 * * *$ & $0.666 * * 2$ & $-19.03 * \%$ & -6.774 & $-1.784 \%$ & $-13.39 * * *$ \\
\hline 1798-1806 x wealth & & ref. & & ref. & & $\mathrm{n} / \mathrm{a}$ \\
\hline $1807-1812 \mathrm{x}$ wealth & & $-0.0258 *$ & & 0.381 & & ref. \\
\hline $1813-1817 \mathrm{x}$ wealth & & $-0.0445 * * *$ & & $-2.142 *$ & & $1.013 *$ \\
\hline $1818-1822 \mathrm{x}$ wealth & & $-0.0647 * \cdots$ & & $-3.187 \% *$ & & $2.199 * *$ \\
\hline $1823-1828 \times$ wealth & & $-0.0771 * * *$ & & $-2.040 \%$ & & $2.116 * * *$ \\
\hline Constant & $-1.840 * * *$ & $-2.160 * * *$ & $-9.219 \div 2 * 0$ & $-19.63 \% *$ & $73.47 \% \div$ & $82.09 * * *$ \\
\hline Observations & 34,526 & 34,526 & 25,395 & 25,396 & 25,882 & 25,882 \\
\hline Pseudo R2 & 0.1008 & 0.1015 & 0.0533 & 0.055 & 0.006 & 0.009 \\
\hline
\end{tabular}

Notes: ${ }^{* * *} \mathrm{p}<0.0 \mathrm{I},{ }^{* *} \mathrm{p}<0.05,{ }^{*} \mathrm{p}<0 . \mathrm{I}$.

Ref. period in models 5 and 6 is I 807 -I 8 I 2 as capital values only appear in the opgaafrol consistently after i 805 .

Table A2. Estimates from linked sub-sample negative binomial regressions.

\begin{tabular}{|c|c|c|}
\hline \multirow[b]{3}{*}{ Specification } & \multicolumn{2}{|c|}{ Settler children } \\
\hline & \multicolumn{2}{|c|}{$N B R E G$} \\
\hline & (1) & (2) \\
\hline Livestock wealth & $0.117 * * *$ & $0.162 * * *$ \\
\hline Non-family labour & $0.0231 \%$ & 0.0203 \\
\hline Age & $0.177 * * *$ & $0.177 * * *$ \\
\hline Age2 & $-0.00196 * * 2$ & $-0.00196 * * *$ \\
\hline $1798-1806$ & ref. & ref. \\
\hline $1807-1812$ & $0.0742 \% * *$ & $0.265 \% *$ \\
\hline $1813-1817$ & $0.0853 \% *$ & $0.392 * * *$ \\
\hline $1818-1822$ & $0.0592 *$ & $0.428 * * *$ \\
\hline $1823-1828$ & $0.0790 * * *$ & $0.467 * * *$ \\
\hline $1798-1806 \times$ wealth & & ref. \\
\hline $1807-1812 \times$ wealth & & -0.0298 \\
\hline $1813-1817 \mathrm{x}$ wealth & & $-0.0473 *$ \\
\hline $1818-1822 \times$ wealth & & $-0.0574 \% * \%$ \\
\hline $1823-1828 \times$ wealth & & $-0.0605 \% *$ \\
\hline Constant & $-4.477 * * *$ & $-4.768 * * *$ \\
\hline Observations & 16,000 & 16,000 \\
\hline Pseudo R2 & 0.0937 & 0.0941 \\
\hline
\end{tabular}

Notes: ${ }^{* * *} \mathrm{p}<0.0 \mathrm{I},{ }^{* *} \mathrm{p}<0.05,{ }^{*} \mathrm{p}<0 . \mathrm{I}$. 


\author{
TRANSLATED ABSTRACTS \\ FRENCH - GERMAN - SPANISH
}

Jeanne Cilliers et Erik Green. L'bypothèse sur la disponibilité de terres et la main d'œuvre dans une économie de colons: richesse, main d'œuvre et composition $d u$ ménage à la frontière sud-africaine.

La littérature traditionnelle de la frontière identifie une corrélation positive entre la disponibilité de terres et la fertilité. Une explication courante est que la demande de travail des enfants est supérieure dans les régions frontalières nouvellement établies, par comparaison avec d'anciennes régions agricoles plus densément peuplées. Dans cet article, nous contribuons au débat en analysant la relation entre la composition du ménage et la disponibilité de terres dans une région frontalière en train de fermer, le district de Graaff-Reinert dans la Colonie du Cap en Afrique du Sud, entre 1798 et I 828. Les auteurs montrent que le nombre des enfants dans les ménages agricoles augmenta avec la fermeture des frontières, tandis que la présence d'ouvriers agricoles non familiaux déclina au fil des ans. Contrairement à l'interprétation classique, nous expliquons ce phénomène en reconnaissant que la demande de travailleurs familiaux ne dépendit pas de sa productivité marginale, et que les exploitants agricoles réagirent différemment selon leur richesse à la disponibilité de terres diminuante. Les foyers plus pauvres, qui constituaient la majorité de cette population frontalière, répondirent à la disponibilité de terres déclinante en employant relativement plus de main d'œuvre familiale, tandis que le groupe le plus riche investit dans le renforcement de l'accès au marché.

Traduction: Christine Plard

Jeanne Cilliers und Erik Green. Die Land/Arbeitskraft-These in der Siedlerökonomie: Woblstand, Arbeitskraft und Haushaltszusammensetzung im südafrikanischen Grenzgebiet.

Die traditionelle Literatur zu Grenzgebieten verweist auf eine positive Korrelation zwischen der Verfügbarkeit von Ländereien und der Fertilität der Bevölkerung. Eine gängige Erklärung lautet, dass in neu entstandenen Grenzgebieten eine stärkere Nachfrage nach Kinderarbeit besteht als in älteren, dichter besiedelten landwirtschaftlichen Gebieten. Der Artikel leistet einen Beitrag zur Debatte, indem er dem Zusammenhang von Haushaltszusammensetzung und der Verfügbarkeit von Ländereien in einem sich stabilisierenden Grenzgebiet der südafrikanischen Kapkolonie, dem Graaff-Reinet-Distrikt zwischen 1798-1828, nachgeht. Es wird gezeigt, dass die Kinderzahl in den landwirtschaftlich tätigen Haushalten mit der Stabilisierung des Grenzgebiets zugenommen hat, wohingegen die Zahl nichtfamiliärer Arbeitskräfte rückläufig war. Dieser der klassischen Interpretation entgegenstehende Befund wird durch den Hinweis erklärt, dass die Nachfrage nach familiärer Arbeitskraft keine Funktion der Grenzproduktivität dieser Arbeitskraft war; darüber hinaus reagierten Landwirte, je nach ihrem Wohlstand, unterschiedlich auf die Verknappung verfügbaren Landes. Ärmere Haushalte, die im Grenzgebiet die Mehrheit stellten, reagierten auf den Schwund an verfügbarem Land durch eine 
relative Steigerung der Beschäftigung familiärer Arbeitskräfte, wohingegen die Gruppe der wohlhabendsten Siedler in die Ausweitung des Marktzugangs investierte.

Übersetzung: Max Henninger

Jeanne Cilliers y Erik Green. La hipótesis tierra-trabajo en una economia de colonos: Riqueza, trabajo y composición familiar en la frontera sudafricana.

La tradicional literatura de frontera identifica una correlación positiva entre la disponibilidad de tierras y la fertilidad. Una explicación común es que la demanda de trabajo infantil es mayor en las regiones fronterizas establecidas en tiempo reciente en comparación con las regiones agrícolas más antiguas y más densamente pobladas. En el artículo que presentamos pretendemos contribuir a la discusión aportando el análisis de la relación entre la composición familiar y la disponibilidad de tierras en una región fronteriza consolidada, como es el distrito de Graaf-Reinet en la colonia de El Cabo en Sudáfrica en el periodo de I798-I828. El texto muestra que el número de niños en los hogares agrícolas se incrementa con la consolidación de la frontera, mientras que la presencia de trabajadores no pertenecientes a la familia irá disminuyendo en el trascurso del tiempo. En contraste con la interpretación clásica, esto lo explicamos mediante el reconocimiento de que la demanda de trabajo familiar no era una función de su productividad marginal y que los agricultores reaccionaron de forma distinta a la disminución de las tierras disponibles dependiendo de su riqueza. Los hogares más pobres, que constituían la mayoría de esta población de frontera, respondieron a la disminución de la disponibilidad de tierras empleando relativamente más mano de obra familiar, mientras que el grupo de los hogares más ricos invirtió en fortalcer su acceso a los mercados. 